\title{
The Rise and Fall of Social Democracy, 1918-2017*
}

\author{
Giacomo Benedetto $^{\dagger}$ Simon Hix Nicola Mastrorocco $^{\S}$
}

April 9, 2020

\begin{abstract}
We describe the electoral history of one of Europe's most successful party families over the past 100 years in 31 countries. With a unique and newly collected dataset of national election results, and a large number of economic and social variables measured for each country-election observation, we find that two main factors drive the electoral performance of social democratic parties: public sector spending, and the size of the manufacturing sector. Our findings suggest that most of the fall in support for social democratic parties in recent years is correlated with a decline in the number of industrial workers as well as a reduction in the propensity of social democratic parties' core supporters (industrial workers and public sector employees) to vote for them.
\end{abstract}

Forthcoming, American Political Science Review

${ }^{*}$ We would like to thank Thomas Koenig and 4 anonymous referees for their useful comments. We also would like to thank Tarik Abou-Chadi, James Adams, Lawrence Ezrow, Christopher Hanretty, Oliver Heath, Sara Hobolt, James Snyder, and Herbert Kitschelt for comments on an earlier version of the paper, and Federico Fabio Frattini, Laura Chitty, Etienne Goh, Fariba Ghazizadeh, and Eponine Howarth for research assistance.

${ }^{\dagger}$ Royal Holloway, University of London, Contact Information: giacomo.benedetto@rhul.ac.uk

${ }^{\ddagger}$ London School of Economics and Political Science, Contact Information: s.hix@lse.ac.uk

§Trinity College Dublin, Contact Information: n.mastrorocco@tcd.ie 


\section{Introduction}

There is a large body of research on the rise of populist parties (e.g. Colantone and Stanig 2018; Dinas et al. 2019; Guiso et al. 2019; Kriesi et al. 2012; Kaltwasser et al. 2017; Eatwell and Goodwin 2018). Less attention has been paid to a corollary of this trend: the electoral decline of the centre left. Across Europe, social democratic parties that once commanded over 40 percent of votes have collapsed to the low twenties, teens, or lower. We do three things to investigate these patterns. First, we describe the variations in support for social democrats over the last century in 31 countries. Second, we undertake a time-series cross-sectional analysis to identify some of the correlates of the electoral fortunes of social democrats. Third, we supplement this aggregate-level analysis by looking at individual-level support for social democratic parties between 2002 and 2016.

Our aim is not to provide a causal explanation of the rise and fall of social democracy. By introducing a new dataset of elections for 31 countries over 100 years, we provide descriptive evidence of a time-consistent relationship between two main factors, public sector spending and industrial production, and votes for social democratic parties. Our findings suggest that most of the fall in support for social democrats is correlated with a decline in the number of industrial workers as well as a reduction in the propensity of these parties' core supporters (industrial workers and public sector employees) to vote for them.

\section{Evolution of Social Democracy}

There has been extensive work on the evolution of social democratic parties. For example, scholars have looked at their formation (e.g. Sassoon 1996; Bartolini 2000), the strategic challenge of appealing to the middle class while maintaining working class support (e.g. Przeworski and Sprague 1986), the rise of a social dimension cross-cutting the traditional left-right (e.g. Kitschelt 1990), how electoral systems shape their behaviour (e.g. Iversen and 
Soskice 2006), and globalization (e.g. Garrett 1998; Boix 1985). We include all the factors discussed in this literature and we complement them with a wide range of other variables, such as public spending, welfare spending, employment in industry, and electoral turnout.

We analyze all democratic elections in Europe over 100 years, starting from 1918. Many European countries extended suffrage at the end of WWI. We define democratic elections as all elections that were held in a year when a country had either a Polity score or a 'Political Competition' score greater than 5. ${ }^{1}$ We count countries that had populations larger than 500,000 in 2017 and who had democratic elections for at least one 20-year period. These criteria produce 579 elections in 31 countries, as Table 1 shows.

Table 1: Democratic elections in Europe, 1918 - 2017

\begin{tabular}{llrr}
\hline \hline Country & Years counted as democratic & $\begin{array}{r}\text { Number } \\
\text { of years }\end{array}$ & $\begin{array}{r}\text { Number of } \\
\text { elections }\end{array}$ \\
\hline Albania & $1992-2017$ & 26 & 8 \\
Austria & $1918-32,1945-2017$ & 88 & 27 \\
Belgium & $1918-38,1944-2017$ & 95 & 29 \\
Bulgaria & $1918-23,1990-2017$ & 35 & 12 \\
Croatia & $1991-2017$ & 27 & 8 \\
Cyprus & $1970-2017$ & 48 & 10 \\
Czechoslovakia/Czech Republic & $1918-38,1945-46,1990-92,1993-2017$ & 51 & 14 \\
Denmark & $1918-39,1943-2017$ & 97 & 38 \\
Estonia & $1918-33,1991-2017$ & 43 & 13 \\
Finland & $1918-39,1944-2017$ & 96 & 29 \\
France & $1918-39,1945-2017$ & 95 & 25 \\
Germany & $1919-32,1949-2017$ & 83 & 28 \\
Greece & $1920-36,1944-48,1974-2017$ & 64 & 24 \\
Hungary & $1920-43,1990-2017$ & 52 & 12 \\
Ireland & $1921-2017$ & 97 & 30 \\
Italy & $1918-21,1946-2017$ & 76 & 20 \\
Latvia & $1920-33,1990-2017$ & 42 & 13 \\
Lithuania & $1991-2017$ & 27 & 7 \\
Luxembourg & $1918-39,1945-2017$ & 95 & 20 \\
Macedonia & $1991-2017$ & 27 & 8 \\
Netherlands & $1918-39,1945-2017$ & 95 & 28 \\
Norway & $1918-39,1945-2017$ & 95 & 26 \\
Poland & $1918-30,1990-2017$ & 41 & 12 \\
Portugal & $1975-2017$ & 43 & 15 \\
Romania & $1925-38,1990-2017$ & 42 & 14 \\
Slovakia & $1993-2017$ & 25 & 7 \\
Slovenia & $1991-2017$ & 27 & 7 \\
Spain & $1977-2017$ & 41 & 13 \\
Sweden & $1918-2017$ & 100 & 29 \\
Switzerland & $1918-2017$ & 100 & 26 \\
United Kingdom & $1918-2017$ & 100 & 27 \\
\hline Total & & & 579 \\
\hline \hline & & &
\end{tabular}

\footnotetext{
${ }^{1}$ See http://www.systemicpeace.org/polityproject.html.
} 
Which parties do we count as social democratic? Usually, only one party was a member of the Socialist International or Party of European Socialists at a particular time. For the cases where several parties were members of these organizations, we combined the vote-shares for these parties - see Appendix Table A1. Parties with different ideological origins at different stages have been described as social democratic, such as the Italian Communist Party (PCI) since the late 1960s. We run two robustness tests to address this issue. First, we estimate the models with the vote-share of all left parties as the dependent variable (social democratic, communist, and green). Second, because of the particular case of Italy, we estimate the models counting the PCI rather than the PSI as the social democratic party in Italy from 1968 onwards, since after that year the PCI became more moderate, the PSI remained in government with the centre right, and the PCI was the main opposition. We put together the data on vote shares from Nohlen and Stoever (2010), and cross-checked the data with national electoral commissions where possible.

Figure 1: Three measures of the electoral performance of social democratic parties

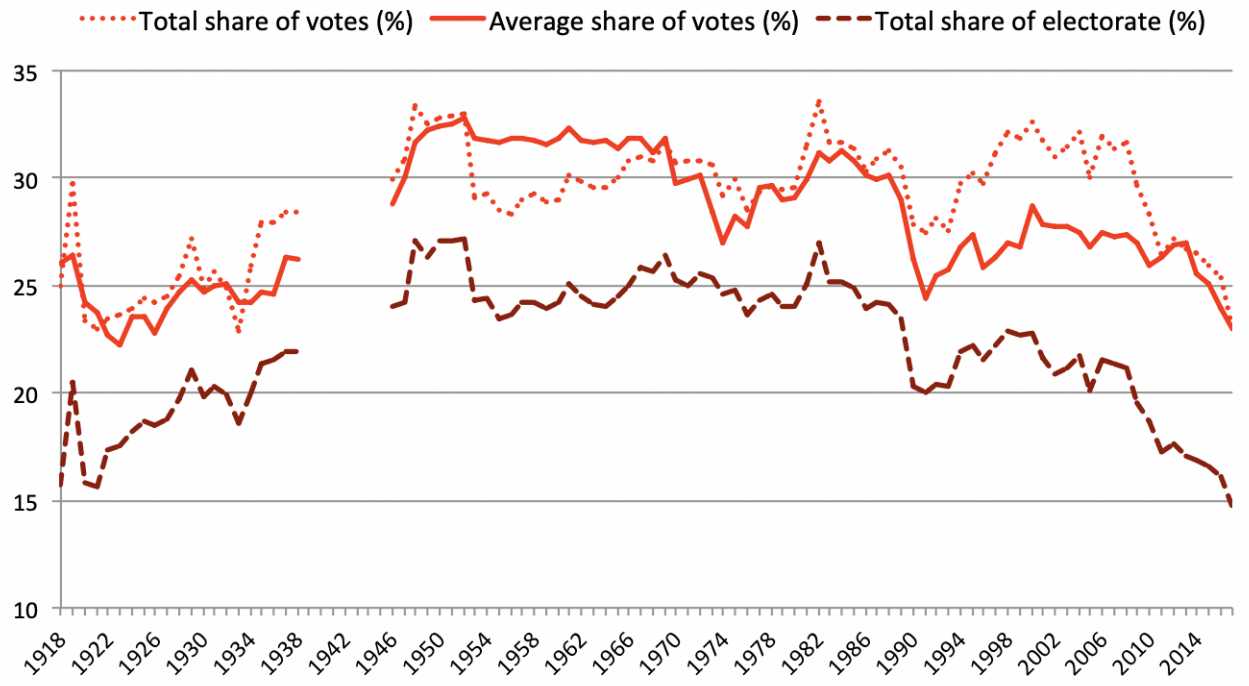

Note: Total share of votes $=$ total votes for social democratic parties in a year in the 31 countries divided by total votes cast in all elections. Total share of the electorate $=$ total votes for social democratic parties in a year in the 31 countries divided by total eligible voters in an election. Average share of votes $=$ average share of votes for social democratic parties in a year in each of the 31 countries. 
Figure 1 exemplifies the breadth of this dataset and shows three measures of social democratic parties' electoral performance. Measured by the average vote share (percent) across our countries in a given year, support for social democrats peaked in the 1950s. Measured by the total share of votes across Europe, support for these parties peaked in the late 1990s, because of the high performance of social democrats in several larger countries (Germany, UK, and Italy). Measured by the total share of the electorate, support for social democrats declined in the late 1980s and fell precipitously in the 2000s (Figures A1-A2).

One issue is that social democracy has meant different things in different periods. The main stages of the evolution of social democracy can be summarized as three 'waves'. Figure 2 shows the periodization of these waves. Here, we coded each party by looking at their positions in manifestos (for the post-1945 period), as well as historical descriptions (for the pre-1945 period) (Jacobs 1989; von Beyme 1985; Sassoon 1996; Bartolini 2000). The first wave, of a parliamentary road to socialism, started after the WWI, when most social democratic parties broke from revolutionary politics and aimed to achieve socialism via a parliamentary route, sometimes blending parliamentary and revolutionary objectives. With the rise of industrial society, many expected these parties to win electoral majorities (cf. Przeworski and Sprague 1986). Indeed, social democrats won over 30 percent of the vote in some of the first elections after WWI (in Germany and Austria). In the mid-1920s, the Swedish and Austrian parties exceeded 40 percent, while the Belgian party reached 39 percent. The 1920s and 1930s also saw brief periods in government for social democrats in Czechoslovakia, Germany, France, the UK, Denmark, Norway, and Sweden, most often in coalition or tolerated by other parties. When in government, social democrat-led reforms included maximum working hours, paid annual leave, collective bargaining, and pensions systems. But, in this period, not all workers supported socialist parties, as some supported Catholic or communist parties. Meanwhile, the social democrat electorate also included agricultural workers and some middle class supporters (Neisse 1930; Lipset 1983). These 
early successes ended with the Great Depression. Democracy collapsed in most of central and eastern Europe while support for social democrats fell in western Europe. There were some exceptions, as social democrats achieved 38 percent in the UK, over 40 percent in Denmark, Sweden, Norway, and Finland, and a historic peak of 29 percent in Switzerland.

Figure 2: Three waves of social democracy

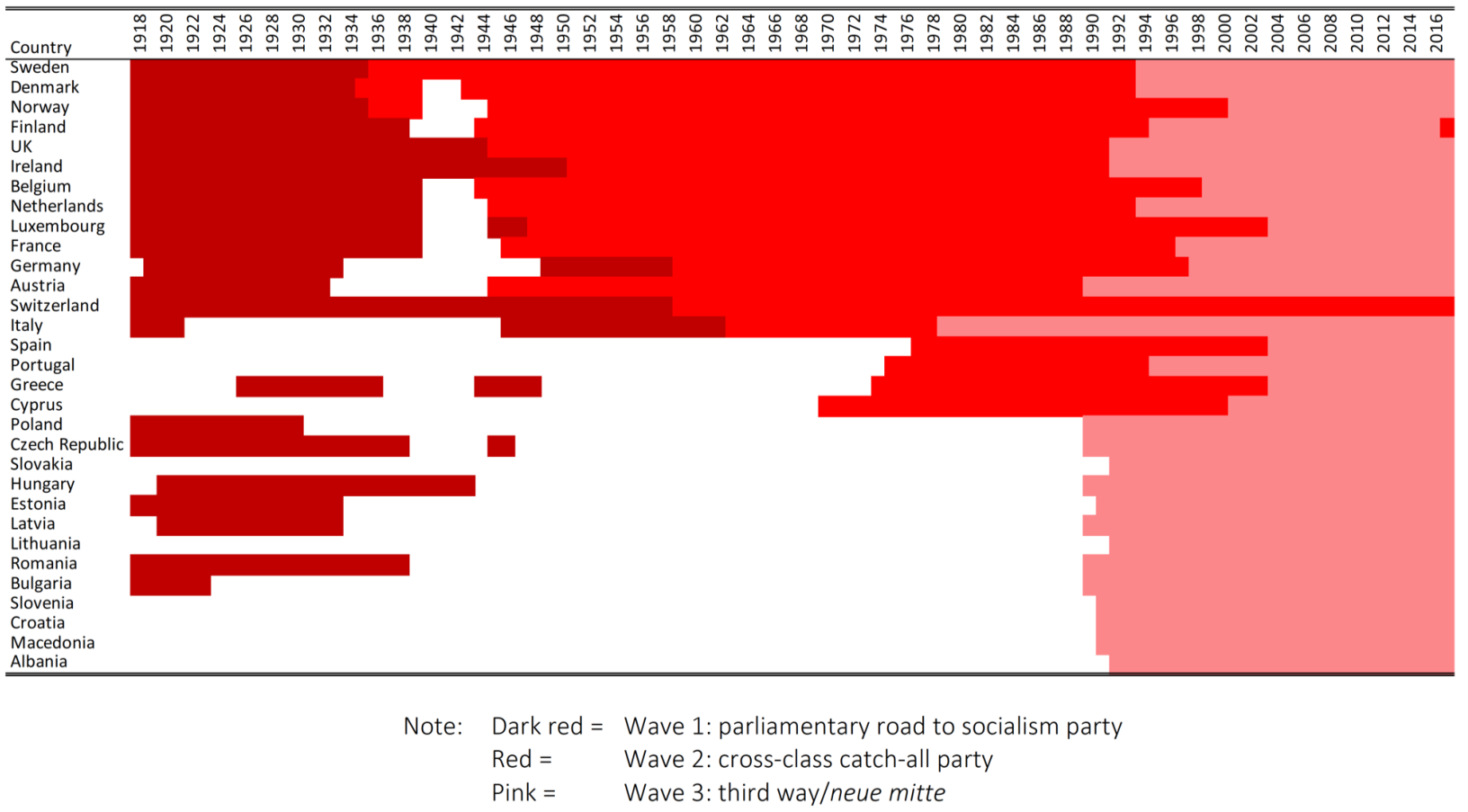

The second wave of social democracy involved the transformation of the parties into mainstream electoral machines. After WWII, most social democratic parties attempted to reach beyond their traditional working class base (e.g. Kirchheimer 1966), accepting that social democrat voting industrial workers were unlikely to generate a majority (Sassoon 1996, p.42). This new strategy started in Scandinavia in the 1930s, then spread to social democratic parties in the UK, France, Austria, Belgium, and the Netherlands in the 1940s, and to Germany, Italy and Switzerland in the 1950s. These 'catch-all' parties downgraded class-based politics, in favour of policies that appealed to public sector employees, urban pro- 
fessionals, and agricultural labour. Many social democrats focused on establishing a social market (an objective shared with Christian democrats), building a welfare state, nationalizing natural monopolies, macroeconomic demand management, and in later yearsliberal social policies on divorce and gender equality. Universal welfare policies also shifted the preferences of sections of the middle class as well as centre right parties (e.g. Gingrich and Häusermann 2015). These shifts enabled social democrats to form governments with liberals and Christian democrats, and in the immediate post-war years social democrats were in government almost everywhere and in single-party governments in the UK, Sweden, and Norway. Most social democratic parties saw their support peak in the 1960s and 1970s, although whether this success was a result of societal changes or moderating party positions cannot be identified with our data.

Following the 1970s oil crisis, changes in global trade patterns and rising unemployment and inflation, market liberalization, and monetarist economics gained momentum, while green movements also squeezed support. European integration, globalization, and the collapse of communism facilitated a renewal of social democracy (e.g. Garrett 1998; Boix 1985). A third wave of social democracy emerged around the idea of a third way or new middle (neue mitte), which emphasized regulating markets, supply-side economic management, balanced budgets, and social liberalism and environmentalism (e.g. Giddens 1998). By 1998, social democrats were back in office in every western European country except Spain, Norway, and Ireland; governing alone in the UK, Portugal, Sweden, and Greece, leading coalitions in Germany, Italy, Denmark, the Netherlands, and France, and serving in grand coalitions with the centre right in Austria, Belgium, Finland, and Switzerland. Also, in central and eastern Europe, former communist leaders used third way social democracy to distance themselves from the past, and emerged as electoral winners except in Estonia, Latvia, Slovenia, and Slovakia.

But, starting in the early 2000s, social democrat support collapsed almost everywhere. 
Between 2000 and 2017 most social democratic parties secured their lowest levels of support since 1918, or 1945 for the post-war democracies, or 1989 for the new democracies in central and eastern Europe. ${ }^{2}$

This suggests that different factors shaped the success of social democratic parties in different periods. In the interwar period, the parties emerged from industrial labour, became more moderate in the postwar period as they expanded support to public sector workers, then adapted their positions following globalization in the 1970s, and faced new challenges following the fall of the Berlin Wall in 1989 and the Great Recession in the 2000s. To investigate this story we look at each of these periods in turn. Empirically, this periodization also fits the availability of data for some key variables. For the interwar period, we found data on manufacturing and public spending, but data on party positions are not available until after WWII, while data on employment in industry and globalization only start in the 1970s. In the empirical analysis we test that our results are not driven by the choice of our periodization, by estimating the models starting 5 years before and after our cutoff years.

\section{Correlates of Electoral Support for Social Demo- cratic Parties}

To understand what factors correlate with these cross-country and cross-time variations we collected a wide range of institutional, economic, social, and political variables. The Appendix contains a full list of variables.

We estimate two different types of time-series cross-sectional models:

$$
V_{i t}=\alpha+\beta W_{i t}+\phi X_{i t}+\gamma_{i}+\theta_{t}+\epsilon_{i t}
$$

\footnotetext{
${ }^{2}$ Few countries bucked this trend. This was the case in Albania, Croatia, Denmark, Portugal, Romania, Spain, and the UK.
} 


$$
\Delta V_{i t}=\alpha+\beta \Delta W_{i t}+\phi \Delta X_{i t}+\gamma_{i}+\theta_{t}+\epsilon_{i t}
$$

Model 1 uncovers long-term changes in the levels of support for social democratic parties, while model 2 (a first-differences model) examines short-term changes, between elections. In the equations, $V$ is a social democratic party percent vote share in country $i$ at time (election) $t ; \alpha$ is a constant; $W$ is a vector of independent variables; $X$ is a vector of control variables; $\gamma$ are country fixed-effects; $\theta$ are decade fixed-effects and country-specific time trends; $\beta$, and $\phi$ are the parameters to be estimated; and $\epsilon$ is the error term. We estimate both types of models with ordinary least squares. This historical longitudinal cross-sectional analysis allows us to tackle such a large and important question. However, it poses a trade-off. Although conditional on a large set of controls and fixed-effects our exercize remains descriptive as this type of time series analysis poses several empirical challenges such as omitted variable bias, unit roots, and time trends interferences. We address some of these issues later. 
Figure 3: Public spending and industrial production in Western Europe

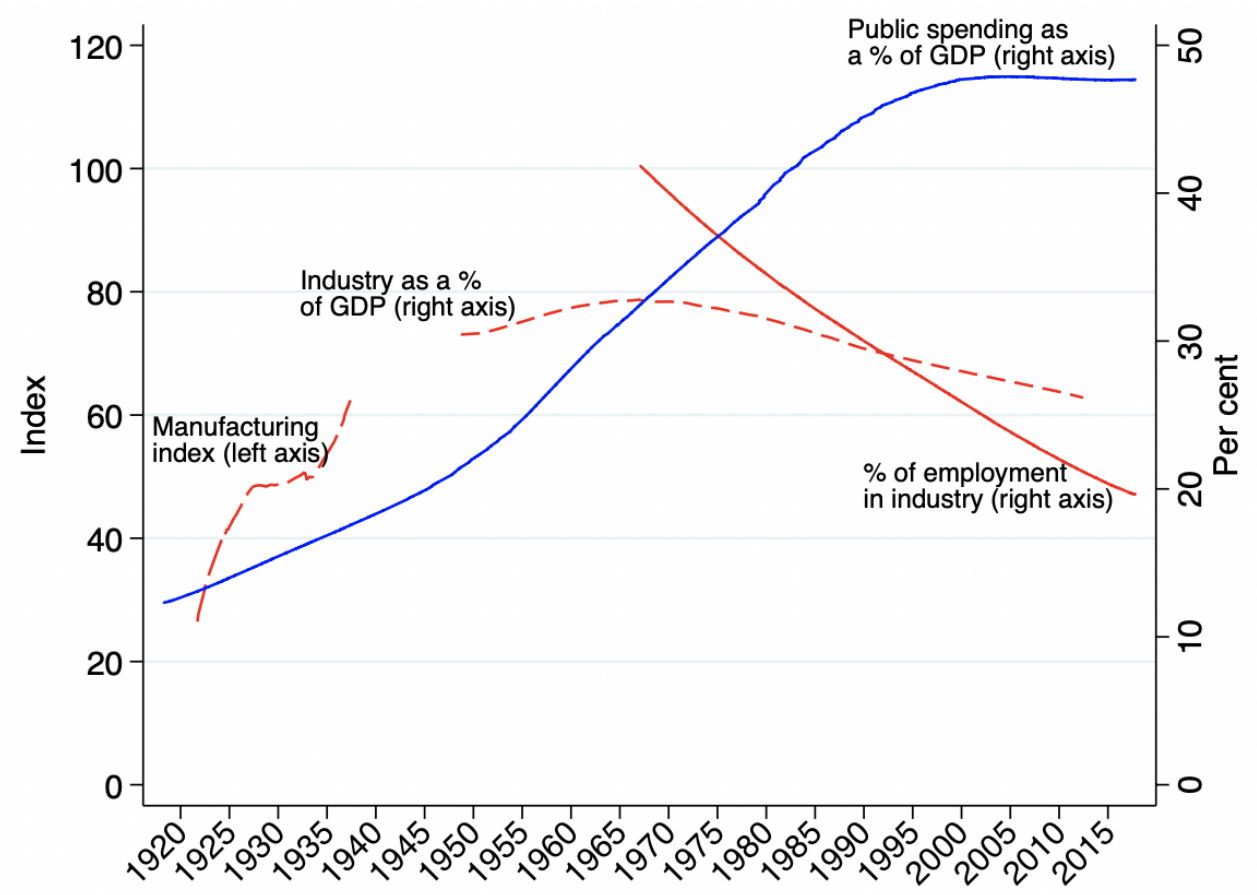

Note: For 18 western European countries, the graph plots measures of public spending as a percent of GDP and our three measures of industry: the manufacturing index, for 1918-1939 (from League of Nations trade data, measuring the volume of trade in manufactured goods relative to 1953); industry as a percent of GDP, for 1950-2017 (share of industrial output as a percent of GDP at constant 2005 prices); and percent of total employment in industry, for 1970-2017. The lines are plotted by locally weighted scatterplot smoothing.

As a start, Figure 3 plots two main independent variables (for 18 western European democracies): public spending as a percent of GDP, and several measures of the size of industry/manufacturing. Public spending increased steadily from the 1920s to the 2000s, consistent with Wagner's (1890) law on developed economies that embark on social progress. ${ }^{3}$ Industrial production rose until the 1970s and then declined dramatically, as a result of structural changes, globalization and technology.

To investigate these relationships further, Table 2 presents the correlates of social democratic party vote shares between 1918 and 1939 for the 16 countries who held democratic elections in this period and with the limited set of available variables. Trade in manufactured

\footnotetext{
${ }^{3}$ Peacock and Wiseman (1961) find consistent growth in public expenditure when Labour held office.
} 
Table 2: Correlates of social democracy party vote shares, 1918-1939

\begin{tabular}{|c|c|c|c|c|c|c|}
\hline & \multicolumn{6}{|c|}{ Analysis of levels } \\
\hline & $(1)$ & $(2)$ & (3) & $(4)$ & $(5)$ & $(6)$ \\
\hline \multirow[t]{2}{*}{ Public spending ( $\%$ of GDP) } & -0.101 & -0.0236 & -0.184 & 0.129 & -0.00593 & 0.109 \\
\hline & $(0.157)$ & $(0.140)$ & $(0.443)$ & $(0.337)$ & $(0.433)$ & $(0.368)$ \\
\hline \multirow[t]{2}{*}{ District magnitude (log) } & -2.344 & -3.327 & $3.597^{*}$ & $6.259^{* * *}$ & 3.731 & $5.130^{*}$ \\
\hline & $(5.917)$ & $(7.156)$ & $(1.727)$ & $(1.583)$ & $(2.299)$ & $(2.411)$ \\
\hline \multirow[t]{2}{*}{ SD party in gov't (single-party) } & -1.108 & -1.955 & 0.238 & -0.199 & 0.355 & 0.0831 \\
\hline & $(2.035)$ & $(2.049)$ & $(2.311)$ & $(2.034)$ & $(1.975)$ & $(1.897)$ \\
\hline \multirow[t]{2}{*}{ SD party in gov't (coalition-PM) } & 0.535 & 0.529 & 1.424 & $2.556^{*}$ & 0.360 & 1.294 \\
\hline & $(3.818)$ & $(2.706)$ & $(1.512)$ & $(1.334)$ & $(1.904)$ & $(1.811)$ \\
\hline \multirow[t]{2}{*}{ SD party in gov't (coalition-junior) } & -0.462 & -2.097 & $-8.349 * * *$ & $-8.993^{* * *}$ & $-9.563^{* * *}$ & $-9.544^{* * *}$ \\
\hline & $(3.600)$ & $(2.596)$ & $(2.382)$ & $(2.030)$ & $(2.229)$ & $(2.084)$ \\
\hline \multirow[t]{2}{*}{ Turnout } & $0.273^{*}$ & 0.194 & 0.198 & 0.0348 & 0.0291 & -0.00804 \\
\hline & $(0.141)$ & $(0.164)$ & $(0.185)$ & $(0.159)$ & $(0.212)$ & $(0.200)$ \\
\hline \multirow[t]{2}{*}{ Manufacturing index } & & & & & $0.260 * *$ & 0.181 \\
\hline & & & & & $(0.0925)$ & $(0.171)$ \\
\hline Observations & 77 & 77 & 49 & 49 & 49 & 49 \\
\hline R-squared & 0.234 & 0.329 & 0.277 & 0.428 & 0.454 & 0.482 \\
\hline \multirow[t]{3}{*}{ Number of countries } & 16 & 16 & 11 & 11 & 11 & 11 \\
\hline & \multicolumn{6}{|c|}{ 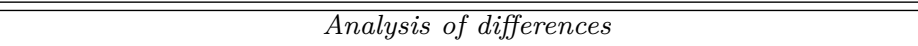 } \\
\hline & $(7)$ & $(8)$ & $(9)$ & $(10)$ & $(11)$ & $(12)$ \\
\hline \multirow[t]{2}{*}{ Public spending ( $\%$ of GDP) } & -0.0487 & -0.0589 & 0.0642 & 0.0940 & 0.448 & 0.431 \\
\hline & $(0.144)$ & $(0.149)$ & $(0.171)$ & $(0.175)$ & $(0.534)$ & $(0.476)$ \\
\hline \multirow[t]{2}{*}{ District magnitude (log) } & -2.339 & -0.918 & -3.679 & 0.435 & 5.751 & 6.450 \\
\hline & $(9.189)$ & $(7.545)$ & $(8.628)$ & $(5.080)$ & $(4.596)$ & $(5.372)$ \\
\hline \multirow[t]{2}{*}{ SD party in gov't (single-party) } & $-1.987^{* * *}$ & $-1.869^{* *}$ & $-2.017^{* *}$ & -1.532 & $-2.381^{* *}$ & $-2.049^{* *}$ \\
\hline & $(0.661)$ & $(0.730)$ & $(0.748)$ & $(0.876)$ & $(0.804)$ & $(0.812)$ \\
\hline \multirow[t]{2}{*}{ SD party in gov't (coalition-PM) } & -0.853 & -0.316 & -1.604 & -0.461 & -1.576 & 0.302 \\
\hline & $(1.531)$ & $(2.159)$ & $(1.909)$ & $(3.097)$ & $(1.618)$ & $(2.868)$ \\
\hline \multirow[t]{2}{*}{ SD party in gov't (coalition-junior) } & $-2.447^{*}$ & $-2.848^{* *}$ & $-8.183^{*}$ & -11.32 & -7.460 & -6.974 \\
\hline & $(1.178)$ & $(1.075)$ & $(4.466)$ & $(7.528)$ & $(4.717)$ & $(4.475)$ \\
\hline \multirow[t]{2}{*}{ Turnout } & -0.125 & -0.128 & -0.139 & -0.179 & -0.318 & -0.336 \\
\hline & $(0.312)$ & $(0.307)$ & $(0.470)$ & $(0.477)$ & $(0.384)$ & $(0.415)$ \\
\hline \multirow[t]{2}{*}{ Manufacturing index } & & & & & 0.0307 & -0.0251 \\
\hline & & & & & $(0.118)$ & $(0.140)$ \\
\hline Observations & 61 & 61 & 38 & 38 & 38 & 38 \\
\hline R-squared & 0.063 & 0.077 & 0.107 & 0.163 & 0.214 & 0.247 \\
\hline Number of countries & 15 & 15 & 10 & 10 & 10 & 10 \\
\hline Country fixed-effects & Yes & Yes & Yes & Yes & Yes & Yes \\
\hline Decade fixed-effects & Yes & Yes & Yes & Yes & Yes & Yes \\
\hline Country-year time trends & No & Yes & No & Yes & No & Yes \\
\hline
\end{tabular}

Note: Dependent variable: social democratic party vote share. Models 1 to 6 estimate effects on the overall level of support for social democratic parties. Models 7 to 12 estimate changes in support between elections (first differences). From Model 3, the sample composed by the sub-set of countries for which the manufacturing index is available. Manufacturing Index available for: Austria, Belgium, Denmark, Finland, France, Germany, Italy, Netherlands, Norway, Sweden, and United Kingdom.

goods in this early period is strongly correlated with votes for social democratic parties. We do not find evidence that public spending was related to support for social democrats in this period. Together, these findings are consistent with the description of wave 1 social democratic parties, who based their support on industrial labour. Third, when these parties made 
it into government, they generally lost support, whether as a single party of government or as a senior or junior coalition partner. This result is consistent for all the periods we look at.

Table 3: Correlates of social democracy party vote shares, 1945-2017

\begin{tabular}{lcccc}
\hline \hline & \multicolumn{2}{c}{ Analysis } & of levels & \multicolumn{2}{c}{ Analysis } & of & differences \\
& $(1)$ & $(2)$ & $(3)$ & $(4)$ \\
\hline \multirow{3}{*}{ Public Spending (\% of GDP) } & & & & \\
& $0.157^{* *}$ & $0.193^{* * *}$ & $0.168^{* *}$ & $0.163^{* *}$ \\
Social Democrat left-right position & $(0.0577)$ & $(0.0586)$ & $(0.0725)$ & $(0.0729)$ \\
& $0.172^{* *}$ & $0.170^{*}$ & $0.148^{* *}$ & $0.150^{* *}$ \\
Centre Right left-right position & $(0.0812)$ & $(0.0839)$ & $(0.0684)$ & $(0.0687)$ \\
& -0.00290 & -0.00343 & -0.0357 & -0.0357 \\
District magnitude (log) & $(0.0358)$ & $(0.0346)$ & $(0.0299)$ & $(0.0297)$ \\
& 0.574 & 0.787 & 0.948 & 0.912 \\
District mag.*SD left-right position & $(1.292)$ & $(1.308)$ & $(1.596)$ & $(1.581)$ \\
& $-0.0576^{*}$ & $-0.0552^{*}$ & $-0.0614^{* *}$ & $-0.0619^{* *}$ \\
SD party in gov't (single-party) & $(0.0298)$ & $(0.0316)$ & $(0.0265)$ & $(0.0266)$ \\
& 1.335 & 1.097 & $-3.175^{* * *}$ & $-3.187^{* * *}$ \\
SD party in gov't (coalition-PM) & $(1.256)$ & $(1.230)$ & $(0.957)$ & $(0.962)$ \\
& 0.976 & 0.634 & $-2.507^{* *}$ & $-2.506^{* *}$ \\
SD party in gov't (coalition-junior) & $(1.327)$ & $(1.285)$ & $(0.963)$ & $(0.966)$ \\
& $-2.849^{* * *}$ & $-3.056^{* * *}$ & $-2.461^{* * *}$ & $-2.451^{* * *}$ \\
Turnout & $(0.912)$ & $(0.925)$ & $(0.721)$ & $(0.721)$ \\
& -0.0839 & -0.0861 & $0.300^{* *}$ & $0.299^{* *}$ \\
& $(0.106)$ & $(0.101)$ & $(0.130)$ & $(0.129)$ \\
\hline Controls & Yes & Yes & Yes & Yes \\
Country fixed-effects & Yes & Yes & Yes & Yes \\
Decade fixed-effects & Yes & Yes & Yes & Yes \\
Country-year time trends & No & Yes & No & Yes \\
\hline Observations & 381 & 381 & 353 & 353 \\
R-squared & 0.162 & 0.176 & 0.169 & 0.170 \\
Number of countries & 31 & 31 & 31 & 31 \\
\hline \hline
\end{tabular}

Note: Dependent variable: social democratic party vote share. Models 1 and 2 estimate effects on the overall level of support for social democratic parties. Models 3 and 4 estimate changes in support between elections (first differences). Controls: GDP per capita (log), GDP growth, EU member, Eurozone member, presidential system. Full results in Appendix Table A3.

Table 3 presents the correlates of social democratic party vote shares between 1945 and 2017. Because of data availability we add several economic control variables as well as some key political variables, in particular the left-right locations of social democratic and centre right parties (from party manifestos), as well as the interaction of left-right party positions 
and the electoral system. We include the policy positions of centre right parties as these were the main competitors for social democratic parties in most countries. We accept that the positions of other parties are also relevant, particularly for the decline of social democratic parties in more recent periods.

Several results are worth highlighting. First, public spending after 1945 is positively related to support for social democratic parties, and this result holds both for the long-term trends as well as for short-term (between election) changes. The effect is sizeable too: a one standard deviation increase in public spending is associated with an increase of about $1.5 \%$ in vote share for social democratic parties. What we do not know from this result, though, is whether more public spending leads to more support for social democrats or whether a larger public sector means more workers with an interest in voting social democrat. ${ }^{4}$

Second, regarding party positions, we find evidence that social democratic parties gained votes when they moved to the centre (closer to the median voter) and lost votes when they moved to the left. We do not find an effect of the left-right position of the main centre right competitor on social democratic support. We replicated this analysis breaking the left-right down into separate economic and social dimensions - see Appendix Table A6 - and we found that social democratic parties won more votes when they were more free market on the economic dimension but more conservative on the social dimension. These results challenge some existing research, for example, that there is little evidence of the link between parties' positions and their electoral performance (e.g. Adams 2012), and Kitschelt 's (1990) contention that social democrats should gain support as they become left-libertarian. However, further investigation reveals that this result on the social dimension is mainly driven by parties in Eastern Europe (after 1989), where several parties, in Romania and Slovakia for example, became socially conservative from the early 2000s and gained votes at the expense of more liberal-cosmopolitan parties. In contrast, there is little evidence

\footnotetext{
${ }^{4}$ We know that public spending can also rise when social democrats are not in office (Borooah 1987).
} 
in western Europe of a connection between social democratic parties' positions on a social dimension and their electoral performance.

We also find that the electoral effect of social democratic parties' positions is magnified by the electoral system. We find an interaction between the electoral system and the left-right position of a party, such that the larger the district magnitude, the lower the support for a social democratic party as the party moves rightwards. Intuitively, this is consistent with existing theory (e.g. Przeworski and Sprague 1986; Iversen and Soskice 2006), which highlights the threat of being outflanked by more left-wing parties in countries with proportional electoral systems. So, in higher district magnitude (proportional) electoral systems, social democratic parties lost support as they become more centrist whereas in lower magnitude (majoritarian) systems, they gained support as they moved towards the median voter.

Table 4 presents the results for the era of globalization, after 1975. Data availability enables us to add a number of new control variables. In particular, we include a globalization index, which combined 43 economic, social, and political variables, such as net and total trade volume, net immigration and total foreign born population, technological integration, and so on (Dreher 2006; Gygli et al. 2019). We also now include welfare spending as a percent of GDP. This allows us to look at public spending on redistribution as opposed to total public spending, which also includes public employment. As before, we find a statistically significant correlation between public spending and social democratic support. In addition, we find that the magnitude of the relationship between public spending on welfare and social democratic support is over twice the size of the magnitude of the relationship between total public spending and social democratic vote shares. This suggests that social democrats benefitted both from more public sector employment and greater wealth redistribution.

Another key result is the relationship between employment in industry and support for social democrats. Again, the results lend support for the proposition that industrial workers have been their core supporters, and hence that the decline in industry since the 1970s is 
Table 4: Correlates of social democratic votes in the era of globalization, 1975-2017

\begin{tabular}{|c|c|c|c|c|c|c|c|c|}
\hline & \multicolumn{4}{|c|}{ Analysis of levels } & \multicolumn{4}{|c|}{ Analysis of differences } \\
\hline & $(1)$ & $(2)$ & $(3)$ & $(4)$ & $(5)$ & $(6)$ & $(7)$ & $(8)$ \\
\hline Public spending ( $\%$ of GDP) & $\begin{array}{l}0.249^{*} \\
(0.129)\end{array}$ & & $\begin{array}{l}0.222^{*} \\
(0.122)\end{array}$ & & $\begin{array}{c}0.229^{* *} \\
(0.110)\end{array}$ & & $\begin{array}{c}0.206 \\
(0.125)\end{array}$ & \\
\hline Welfare spending ( $\%$ of GDP) & & $\begin{array}{c}0.509^{* *} \\
(0.243)\end{array}$ & & $\begin{array}{c}0.532^{* *} \\
(0.239)\end{array}$ & & $\begin{array}{c}0.839^{* *} \\
(0.318)\end{array}$ & & $\begin{array}{c}0.864^{* *} \\
(0.327)\end{array}$ \\
\hline Employment in industry (\%) & $\begin{array}{c}0.981^{* * *} \\
(0.277)\end{array}$ & $\begin{array}{c}0.970^{* *} \\
(0.348)\end{array}$ & $\begin{array}{c}0.866^{* * *} \\
(0.274)\end{array}$ & $\begin{array}{c}0.862^{* *} \\
(0.324)\end{array}$ & $\begin{array}{c}0.147 \\
(0.327)\end{array}$ & $\begin{array}{c}0.224 \\
(0.334)\end{array}$ & $\begin{array}{c}0.167 \\
(0.330)\end{array}$ & $\begin{array}{c}0.207 \\
(0.323)\end{array}$ \\
\hline Social Dem. left-right position & $\begin{array}{c}0.102^{* *} \\
(0.048)\end{array}$ & $\begin{array}{c}0.046 \\
(0.034)\end{array}$ & $\begin{array}{c}0.100^{* *} \\
(0.048)\end{array}$ & $\begin{array}{c}0.049 \\
(0.035)\end{array}$ & $\begin{array}{c}0.029 \\
(0.038)\end{array}$ & $\begin{array}{c}0.040 \\
(0.026)\end{array}$ & $\begin{array}{c}0.032 \\
(0.039)\end{array}$ & $\begin{array}{c}0.040 \\
(0.026)\end{array}$ \\
\hline Centre Right left-right position & $\begin{array}{l}-0.006 \\
(0.051)\end{array}$ & $\begin{array}{c}0.062 \\
(0.053)\end{array}$ & $\begin{array}{l}-0.008 \\
(0.051)\end{array}$ & $\begin{array}{c}0.049 \\
(0.055)\end{array}$ & $\begin{array}{l}-0.051 \\
(0.043)\end{array}$ & $\begin{array}{l}-0.024 \\
(0.036)\end{array}$ & $\begin{array}{l}-0.050 \\
(0.042)\end{array}$ & $\begin{array}{c}-0.024 \\
(0.037)\end{array}$ \\
\hline SD party in gov't (single-party) & $\begin{array}{l}-0.347 \\
(1.451)\end{array}$ & $\begin{array}{l}-0.148 \\
(1.826)\end{array}$ & $\begin{array}{l}-0.598 \\
(1.431)\end{array}$ & $\begin{array}{c}-0.524 \\
(1.806)\end{array}$ & $\begin{array}{c}-3.523^{* *} \\
(1.393)\end{array}$ & $\begin{array}{c}-3.908^{* *} \\
(1.428)\end{array}$ & $\begin{array}{c}-3.456^{* *} \\
(1.397)\end{array}$ & $\begin{array}{c}-3.954^{* *} \\
(1.407)\end{array}$ \\
\hline Turnout & $\begin{array}{c}0.121 \\
(0.148)\end{array}$ & $\begin{array}{c}0.072 \\
(0.157)\end{array}$ & $\begin{array}{c}0.100 \\
(0.139)\end{array}$ & $\begin{array}{c}0.038 \\
(0.142)\end{array}$ & $\begin{array}{l}0.313^{*} \\
(0.171)\end{array}$ & $\begin{array}{l}-0.003 \\
(0.208)\end{array}$ & $\begin{array}{l}0.309 * \\
(0.167)\end{array}$ & $\begin{array}{l}-0.000 \\
(0.207)\end{array}$ \\
\hline Controls & Yes & Yes & Yes & Yes & Yes & Yes & Yes & Yes \\
\hline Country fixed-effects & Yes & Yes & Yes & Yes & Yes & Yes & Yes & Yes \\
\hline Decade fixed-effects & Yes & Yes & Yes & Yes & Yes & Yes & Yes & Yes \\
\hline Country-year time trends & No & No & Yes & Yes & No & No & Yes & Yes \\
\hline Observations & 244 & 193 & 244 & 193 & 227 & 171 & 227 & 171 \\
\hline R-squared & 0.223 & 0.308 & 0.240 & 0.335 & 0.234 & 0.343 & 0.239 & 0.344 \\
\hline Number of countries & 27 & 22 & 27 & 22 & 27 & 22 & 27 & 22 \\
\hline
\end{tabular}

Note: Dependent variable: social democratic party vote share. Models 1 to 4 estimate effects on the overall level of support for social democratic parties. Models 5 to 8 estimate changes in support between elections (first differences). Controls: union density, district magnitude, employment in agriculture, women in work, urban population, life expectancy, population (log), population aged 65 and over, population aged 0 to 14, percent in higher education. Full results in Appendix Table A4.

one of the key reasons for the long-term decline in their support. We find little evidence that short-term changes in industrial employment affects social democratic support. We also do not find a relationship between globalization and support for social democrats. But, we do find a negative relationship between union density and social democratic support, which runs counter to some existing views about the power of unions and support for wealth redistribution (e.g. Crouch 2017).

Table 5 shows the results for 1989 to 2017, for the post-Cold War period (1989-2017) and the post-Great Recession period (2000-17). Again, the public spending variables are signifi- 
Table 5: Correlates of social democratic votes after the Cold War and the Great Recession

\begin{tabular}{|c|c|c|c|c|c|c|c|c|}
\hline & \multicolumn{4}{|c|}{ Post-Cold War (1989-2017) } & \multicolumn{4}{|c|}{ Post-Great Recession (2000-2017) } \\
\hline & $(1)$ & (2) & (3) & $\begin{array}{l}\text { Analysis } \\
(4)\end{array}$ & $\begin{array}{r}\text { of levels } \\
(5)\end{array}$ & (6) & (7) & $(8)$ \\
\hline Public spending ( $\%$ of GDP) & $\begin{array}{c}0.269 \\
(0.166)\end{array}$ & & $\begin{array}{c}0.223 \\
(0.153)\end{array}$ & & $\begin{array}{c}0.818^{* *} \\
(0.304)\end{array}$ & & $\begin{array}{c}0.792^{* *} \\
(0.293)\end{array}$ & \\
\hline Welfare spending (\% of GDP) & & $\begin{array}{c}0.815^{* *} \\
(0.385)\end{array}$ & & $\begin{array}{c}0.750^{* *} \\
(0.353)\end{array}$ & & $\begin{array}{c}1.900 * * * \\
(0.574)\end{array}$ & & $\begin{array}{c}1.873^{* * *} \\
(0.493)\end{array}$ \\
\hline Employment in industry (\%) & $\begin{array}{l}0.628^{*} \\
(0.338)\end{array}$ & $\begin{array}{l}1.265^{* *} \\
(0.462)\end{array}$ & $\begin{array}{c}0.462 \\
(0.375)\end{array}$ & $\begin{array}{l}1.019^{* *} \\
(0.488)\end{array}$ & $\begin{array}{c}0.632 \\
(0.761)\end{array}$ & $\begin{array}{l}1.949^{*} \\
(1.001)\end{array}$ & $\begin{array}{c}0.578 \\
(0.756)\end{array}$ & $\begin{array}{l}1.785^{*} \\
(1.022)\end{array}$ \\
\hline Globalization index & $\begin{array}{c}0.373 \\
(0.424)\end{array}$ & $\begin{array}{c}0.534 \\
(0.475)\end{array}$ & $\begin{array}{c}0.438 \\
(0.423)\end{array}$ & $\begin{array}{c}0.711 \\
(0.441)\end{array}$ & $\begin{array}{c}0.983^{* *} \\
(0.366)\end{array}$ & $\begin{array}{l}1.118^{*} \\
(0.623)\end{array}$ & $\begin{array}{c}1.106^{* *} \\
(0.424)\end{array}$ & $\begin{array}{l}1.493^{*} \\
(0.753)\end{array}$ \\
\hline Social Democrat left-right position & $\begin{array}{l}0.135^{*} \\
(0.072)\end{array}$ & $\begin{array}{c}0.054 \\
(0.053)\end{array}$ & $\begin{array}{l}0.139^{*} \\
(0.070)\end{array}$ & $\begin{array}{c}0.059 \\
(0.050)\end{array}$ & $\begin{array}{c}0.029 \\
(0.061)\end{array}$ & $\begin{array}{c}0.114 \\
(0.097)\end{array}$ & $\begin{array}{c}0.035 \\
(0.064)\end{array}$ & $\begin{array}{c}0.133 \\
(0.100)\end{array}$ \\
\hline Centre Right left-right position & $\begin{array}{c}0.008 \\
(0.052)\end{array}$ & $\begin{array}{c}0.069 \\
(0.056)\end{array}$ & $\begin{array}{c}0.009 \\
(0.052)\end{array}$ & $\begin{array}{c}0.060 \\
(0.060)\end{array}$ & $\begin{array}{c}-0.137^{*} \\
(0.067)\end{array}$ & $\begin{array}{l}-0.006 \\
(0.066)\end{array}$ & $\begin{array}{c}-0.143^{* *} \\
(0.064)\end{array}$ & $\begin{array}{l}-0.038 \\
(0.068)\end{array}$ \\
\hline SD party in gov't (single-party) & $\begin{array}{l}-2.967 \\
(2.005)\end{array}$ & $\begin{array}{l}-2.371 \\
(2.145)\end{array}$ & $\begin{array}{l}-3.211 \\
(2.078)\end{array}$ & $\begin{array}{l}-3.010 \\
(2.501)\end{array}$ & $\begin{array}{c}0.359 \\
(3.413)\end{array}$ & $\begin{array}{c}-1.581 \\
(4.283)\end{array}$ & $\begin{array}{c}0.153 \\
(3.410)\end{array}$ & $\begin{array}{c}-2.269 \\
(4.348)\end{array}$ \\
\hline SD party in gov't (coalition-PM) & $\begin{array}{l}-0.368 \\
(1.444)\end{array}$ & $\begin{array}{c}0.307 \\
(1.034)\end{array}$ & $\begin{array}{l}-0.492 \\
(1.432)\end{array}$ & $\begin{array}{c}0.033 \\
(1.088)\end{array}$ & $\begin{array}{l}-1.725 \\
(1.557)\end{array}$ & $\begin{array}{c}0.334 \\
(1.482)\end{array}$ & $\begin{array}{l}-1.776 \\
(1.548)\end{array}$ & $\begin{array}{l}-0.103 \\
(1.509)\end{array}$ \\
\hline SD party in gov't (coalition-junior) & $\begin{array}{c}-3.425^{*} \\
(1.923)\end{array}$ & $\begin{array}{c}-4.609 * * \\
(1.709)\end{array}$ & $\begin{array}{l}-3.497^{*} \\
(1.971)\end{array}$ & $\begin{array}{c}-4.983^{* *} \\
(1.873)\end{array}$ & $\begin{array}{c}-4.571 * * \\
(1.767)\end{array}$ & $\begin{array}{l}-3.409 \\
(2.103)\end{array}$ & $\begin{array}{c}-4.757^{* *} \\
(1.797)\end{array}$ & $\begin{array}{l}-4.184^{*} \\
(2.328)\end{array}$ \\
\hline Turnout & $\begin{array}{c}0.116 \\
(0.172)\end{array}$ & $\begin{array}{l}-0.088 \\
(0.191)\end{array}$ & $\begin{array}{c}0.112 \\
(0.172)\end{array}$ & $\begin{array}{l}-0.092 \\
(0.190)\end{array}$ & $\begin{array}{l}-0.007 \\
(0.245)\end{array}$ & $\begin{array}{l}-0.346 \\
(0.265)\end{array}$ & $\begin{array}{c}0.011 \\
(0.234)\end{array}$ & $\begin{array}{l}-0.287 \\
(0.239)\end{array}$ \\
\hline $\begin{array}{l}\text { Observations } \\
\text { R-squared } \\
\text { Number of countries } \\
\end{array}$ & $\begin{array}{c}180 \\
0.204 \\
27 \\
\end{array}$ & $\begin{array}{c}141 \\
0.323 \\
22 \\
\end{array}$ & $\begin{array}{c}180 \\
0.209 \\
27 \\
\end{array}$ & $\begin{array}{c}141 \\
0.341 \\
22 \\
\end{array}$ & $\begin{array}{c}107 \\
0.502 \\
27 \\
\end{array}$ & $\begin{array}{c}84 \\
0.534 \\
22 \\
\end{array}$ & $\begin{array}{c}107 \\
0.505 \\
27 \\
\end{array}$ & $\begin{array}{c}84 \\
0.548 \\
22 \\
\end{array}$ \\
\hline & $(9)$ & $(10)$ & $(11)$ & $\begin{array}{c}\text { Analysis of } \\
(12)\end{array}$ & $\begin{array}{l}\text { differences } \\
(13)\end{array}$ & $(14)$ & $(15)$ & $(16)$ \\
\hline Public spending ( $\%$ of GDP) & $\begin{array}{l}0.281^{*} \\
(0.139)\end{array}$ & & $\begin{array}{l}0.267^{*} \\
(0.142)\end{array}$ & & $\begin{array}{c}0.646^{* *} \\
(0.312)\end{array}$ & & $\begin{array}{c}0.644^{* *} \\
(0.313)\end{array}$ & \\
\hline Welfare spending ( $\%$ of GDP) & & $\begin{array}{c}0.893^{* *} \\
(0.392)\end{array}$ & & $\begin{array}{c}0.918^{* *} \\
(0.382)\end{array}$ & & $\begin{array}{c}1.497^{* *} \\
(0.690)\end{array}$ & & $\begin{array}{l}1.615^{* *} \\
(0.668)\end{array}$ \\
\hline Employment in industry (\%) & $\begin{array}{l}-0.206 \\
(0.345)\end{array}$ & $\begin{array}{c}0.573 \\
(0.398)\end{array}$ & $\begin{array}{c}-0.207 \\
(0.343)\end{array}$ & $\begin{array}{c}0.588 \\
(0.408)\end{array}$ & $\begin{array}{c}0.354 \\
(0.515)\end{array}$ & $\begin{array}{c}0.652 \\
(0.725)\end{array}$ & $\begin{array}{c}0.340 \\
(0.566)\end{array}$ & $\begin{array}{c}0.565 \\
(0.704)\end{array}$ \\
\hline Globalization index & $\begin{array}{c}-0.035 \\
(0.556)\end{array}$ & $\begin{array}{c}0.300 \\
(0.464)\end{array}$ & $\begin{array}{c}-0.031 \\
(0.556)\end{array}$ & $\begin{array}{c}0.283 \\
(0.460)\end{array}$ & $\begin{array}{c}0.423 \\
(0.487)\end{array}$ & $\begin{array}{c}0.281 \\
(0.716)\end{array}$ & $\begin{array}{c}0.434 \\
(0.475)\end{array}$ & $\begin{array}{c}0.568 \\
(0.723)\end{array}$ \\
\hline Social Democrat left-right position & $\begin{array}{c}0.024 \\
(0.055)\end{array}$ & $\begin{array}{c}0.019 \\
(0.047)\end{array}$ & $\begin{array}{c}0.028 \\
(0.056)\end{array}$ & $\begin{array}{c}0.017 \\
(0.047)\end{array}$ & $\begin{array}{l}-0.037 \\
(0.046)\end{array}$ & $\begin{array}{l}-0.007 \\
(0.080)\end{array}$ & $\begin{array}{l}-0.038 \\
(0.045)\end{array}$ & $\begin{array}{l}-0.008 \\
(0.077)\end{array}$ \\
\hline Centre Right left-right position & $\begin{array}{l}-0.054 \\
(0.048)\end{array}$ & $\begin{array}{c}0.000 \\
(0.048)\end{array}$ & $\begin{array}{l}-0.055 \\
(0.048)\end{array}$ & $\begin{array}{c}0.001 \\
(0.048)\end{array}$ & $\begin{array}{c}-0.155^{* * *} \\
(0.048)\end{array}$ & $\begin{array}{l}-0.073 \\
(0.107)\end{array}$ & $\begin{array}{c}-0.155^{* * *} \\
(0.048)\end{array}$ & $\begin{array}{l}-0.076 \\
(0.113)\end{array}$ \\
\hline SD party in gov't (single-party) & $\begin{array}{c}-4.958^{* * *} \\
(1.705)\end{array}$ & $\begin{array}{c}-4.183^{* *} \\
(1.996)\end{array}$ & $\begin{array}{c}-5.046^{* * *} \\
(1.698)\end{array}$ & $\begin{array}{c}-4.099^{*} \\
(2.016)\end{array}$ & $\begin{array}{c}-1.011 \\
(2.040)\end{array}$ & $\begin{array}{l}-4.025 \\
(2.907)\end{array}$ & $\begin{array}{c}-1.018 \\
(2.065)\end{array}$ & $\begin{array}{l}-4.292 \\
(2.825)\end{array}$ \\
\hline SD party in gov't (coalition-PM) & $\begin{array}{c}-4.042^{* * *} \\
(1.177)\end{array}$ & $\begin{array}{c}-3.780 * * * \\
(1.320)\end{array}$ & $\begin{array}{c}-4.053^{* * *} \\
(1.175)\end{array}$ & $\begin{array}{c}-3.793 * * * \\
(1.327)\end{array}$ & $\begin{array}{l}-3.515^{*} \\
(1.829)\end{array}$ & $\begin{array}{l}-2.334 \\
(2.037)\end{array}$ & $\begin{array}{l}-3.511^{*} \\
(1.838)\end{array}$ & $\begin{array}{l}-2.597 \\
(2.042)\end{array}$ \\
\hline SD party in gov't (coalition-junior) & $\begin{array}{c}-4.516^{* * *} \\
(1.258)\end{array}$ & $\begin{array}{c}-5.468^{* * *} \\
(1.430)\end{array}$ & $\begin{array}{c}-4.545^{* * *} \\
(1.243)\end{array}$ & $\begin{array}{c}-5.470^{* * *} \\
(1.453)\end{array}$ & $\begin{array}{c}-4.281^{*} \\
(2.151)\end{array}$ & $\begin{array}{c}-4.740^{*} \\
(2.690)\end{array}$ & $\begin{array}{c}-4.282^{*} \\
(2.162)\end{array}$ & $\begin{array}{c}-4.725^{*} \\
(2.671)\end{array}$ \\
\hline Turnout & $\begin{array}{c}0.312 \\
(0.210)\end{array}$ & $\begin{array}{c}-0.014 \\
(0.228)\end{array}$ & $\begin{array}{c}0.314 \\
(0.211)\end{array}$ & $\begin{array}{c}-0.015 \\
(0.228)\end{array}$ & $\begin{array}{c}0.094 \\
(0.246)\end{array}$ & $\begin{array}{l}-0.085 \\
(0.348)\end{array}$ & $\begin{array}{c}0.096 \\
(0.243)\end{array}$ & $\begin{array}{c}-0.034 \\
(0.331)\end{array}$ \\
\hline Observations & 170 & 136 & 170 & 136 & 107 & 84 & 107 & 84 \\
\hline $\mathrm{R}$-squared & 0.270 & 0.333 & 0.271 & 0.334 & 0.452 & 0.403 & 0.452 & 0.415 \\
\hline Number of countries & 27 & 22 & 27 & 22 & 27 & 22 & 27 & 22 \\
\hline Controls & $\overline{\text { Yes }}$ & Yes & Yes & Yes & $\overline{\text { Yes }}$ & Yes & Yes & Yes \\
\hline Decade fixed-effects & Yes & Yes & Yes & Yes & Yes & Yes & Yes & Yes \\
\hline Country fixed-effects & Yes & Yes & Yes & Yes & Yes & Yes & Yes & Yes \\
\hline Country-year time trends & No & No & Yes & Yes & No & No & Yes & Yes \\
\hline
\end{tabular}

Note: Dependent variable: social democratic party vote share. Columns 1 to 8 estimate effects on the overall level of support for social democratic parties. Columns 9 to 16 estimate changes in support between elections (first differences). Controls: employment in agriculture, district magnitude, women in work, urban population, population (log), population aged 65 and over, population aged 0 to 14, union density, percent in higher education. Full results in Appendix Table A5.

cant, although this time only the welfare spending variable is significant in all specifications. In addition, employment in industry is only significant for 1989-2000, not for 2000-2017. 
This suggests that after the 2008 financial crises, industrial workers had not only declined in numbers, but were now less likely to support social democrats.

Robustness tests: We undertake three robustness tests. First, to test whether our results depend on our definition of social democratic parties, we estimate the models with three alternative dependent variables: (1) our social democratic vote share variable, but counting the Italian Communist Party (PCI) as the social democratic party in Italy from 1968 onwards (instead of the PSI); (2) total left vote share, of all votes for social democrats, radical left, and other left parties; and (3) centre right vote share, of votes for the mainstream centre right parties in each country. The results (in Appendix Tables A8 and A9) reveal that the existing correlation between public spending and social democratic votes is even stronger for the 1945-2017 period when counting the PCI rather than PSI. We also find that the key relationships we uncover only hold consistently for social democratic parties but not for all votes for left parties. Similarly, employment in industry is unrelated to support for the centre right, although there is some evidence that public spending is related to support for the centre right in the 1945-2017 period, but not in the 1975-2017 period. In short, only support for social democratic parties seems closely linked to the size of the manufacturing and public sectors.

Second, to explore the heterogeneity of the effect, we break down the analysis by region. Figure A3 in the Appendix shows the pattern of support for social democratic parties in North-Western Europe, Scandinavia, Southern Europe, and Eastern Europe. These figures show heterogeneity across and within regions, although North Western Europe, Scandinavia and Southern Europe all show a clear 'rise and fall' pattern. We also estimate the models separately for the 18 Western European and 13 Eastern European cases (in Table A10 in the Appendix), and for Southern Europe, Scandinavia, and the rest of Western Europe (in Table A11). The effect of public spending holds for Western Europe and Southern Europe, but when broken down to the smaller number of cases (in A11), the lack of power reduces 
the significance.

Third, given our attempt to trace the arc of social democracy over a century, issues of periodizations are crucial. To test whether our results are driven by our choice of periods, we undertake a sensitivity analysis by randomising when we stop and start the periods we analyze: so, starting in 1950 rather than 1945, in 1970 or 1980 rather than 1975, and in 1985, 1995 or 2005 instead of 2000 or 1989 or 2000 . The results of this analysis (in Appendix A12, A13, and A14) suggest that our choice of periods in the main analysis has no effect on our main results.

\section{Who Votes for Social Democratic Parties?}

The results from this aggregate analysis can only be suggestive of particular relationships between individual voters and social democratic parties. For the most recent period, though, we can see whether the aggregate patterns can be observed at the individual-level, using the European Social Survey (ESS).The eight ESS waves, from 2002 to 2016, cover the period of the Great Recession (2007-10), the refugee crisis (2015-16), and the decline in support for social democratic parties. Fourteen countries in our aggregate data are included in all ESS waves: Belgium, Finland, France, Germany, Hungary, Netherlands, Norway, Poland, Portugal, Slovenia, Spain, Sweden, Switzerland, and United Kingdom.

Following the aggregate results, we focus on the propensity of someone in a manual job in industry ( manufacturing, construction, or extraction) or who was a public sector employee (health and social care, education, or public administration and defence) to vote for a social democratic party. To investigate whether social democratic parties are attracting new professionals, as Kitschelt (1990) and others have suggested, we also include a measure of whether someone is a socio-cultural professional (legal services, the media, the creative industries, and universities) (Oesch 2006). We estimate a linear probability model for each 
wave separately, with country-fixed effects, and we control for a person's gender, whether they live in a city or town, and their age.

The results are summarized in the bottom panel of Figure 4 (see Appendix Table A15). The top panel shows the average percent of employment in manufacturing and the public sector in the 14 countries at the time of each ESS wave, using Eurostat data. Together, these data reveal a particular perspective on the decline of the social democratic electoral coalition. First, while employment in the public sector has remained stable, employment in industry declined by almost 20 percent in just 12 years (from 24.4 to 21.1 percent of the workforce). Second, there has been a decline in support for social democratic parties amongst industrial workers and public sector employees, although public sector employees remain more likely to vote social democrat than industrial workers. In addition, support for social democrats amongst socio-cultural professionals has remained stable. This coheres with Abou-Chadi and Wagner (2019), that social democrats can lose votes if their policies are opposed by (public sector) trade unions, as well as Piketty's (2018) view that social democrats now mainly rely on the support of 'Brahmins', who in our measures are public sector employees and socio-cultural professionals.

In short, in the most recent period, social democratic parties have been hit by a triple effect: 1) there has been a decline in the size of one of the main groups that have traditionally supported social democrats (industrial workers); 2) there has been a decline in the propensity of their core supporters (industrial workers and public sector employees) to vote for them; and 3) these losses have not been compensated by gains in support amongst the newer professional classes. 
Figure 4: Industrial workers, public sector employees, and socio cultural professionals, and social democratic voting

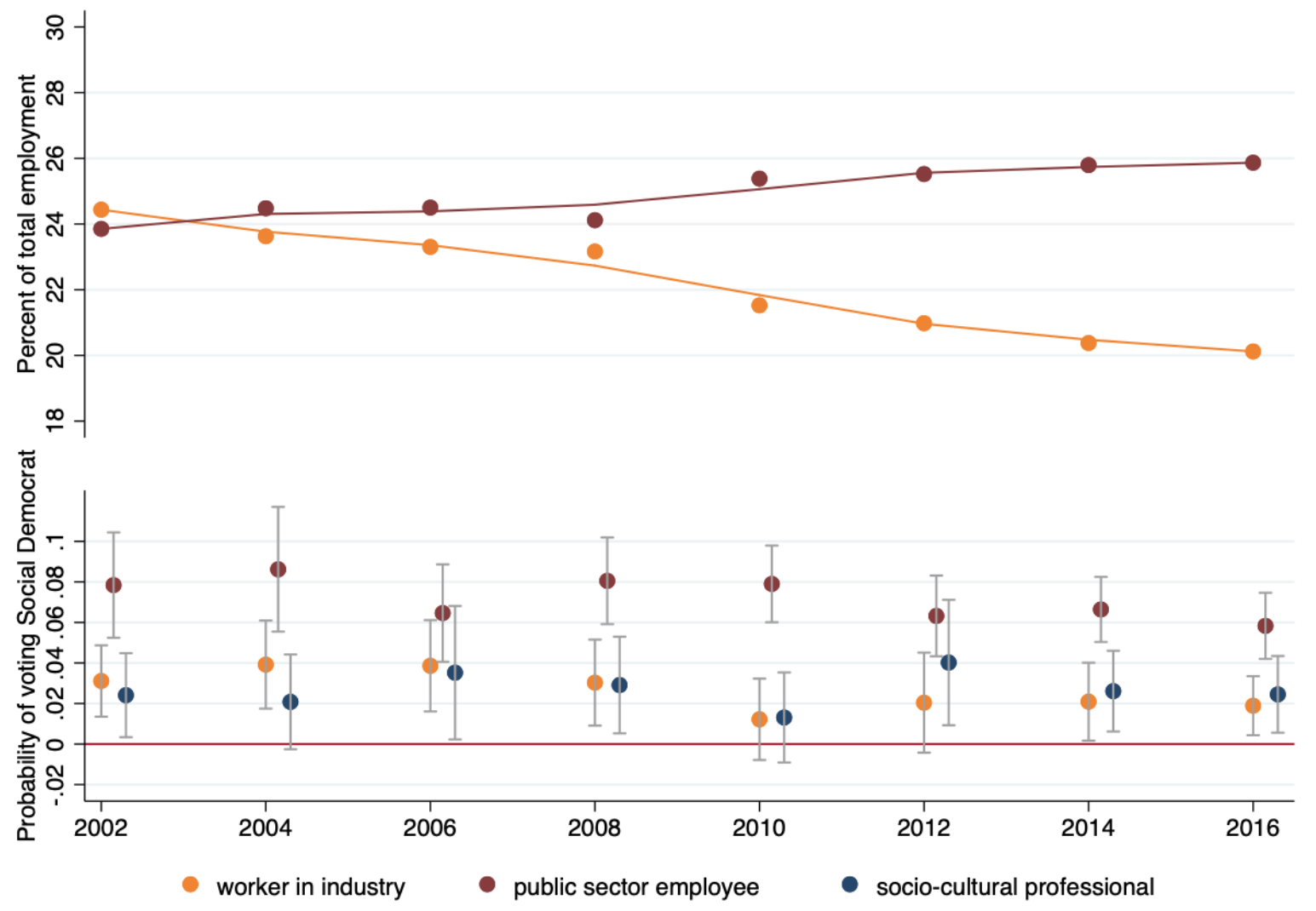

Note: The bottom panel shows the effect of being an industrial worker (extraction, manufacturing, or construction), a public sector employee, or a socio-cultural professional on voting for a social democratic party. The data are from 8 waves of the European Social Survey (ESS) for 14 countries: Belgium, Finland, France, Germany, Hungary, Netherlands, Norway, Poland,

Portugal, Slovenia, Spain, Sweden, Switzerland, and United Kingdom. The models are estimated with country fixed-effects and several socio-demographic control variables. The full results are in Appendix Table A14. The top panel shows the percent of total employment in manufacturing and the public sector in these same 14 countries, from Eurostat

(http://appsso.eurostat.ec.europa.eu), using the same measures for manufacturing and public sector employment as in the ESS.

\section{Conclusion}

The story of the electoral performance of social democracy over the past century is the story of the rise and fall of a particular electoral coalition. Social democratic parties emerged after 1918 to represent the industrial working class. The primary goal of these parties 
was to win an electoral majority and to transform capitalism. This strategy was limited by the size of this social group, and the fact that not all workers supported socialism. Only after social democratic parties moderated their policies (moved closer to the median voter), could the electoral coalition be broadened. By adding another group (public sector workers) to the coalition, social democratic parties started to win between one-third and a half of all votes in many countries. This new coalition established social democrats as one of the main electoral forces in European politics since 1945, on the back of growing public sector employment. From the 1950s to the 1990s social democracy sought to manage or moderate capitalism mainly via increasing public spending. Yet, this coalition unravelled in the 2000s. Globalization and technological change meant that one pillar of this coalition, industrial workers, was now a relatively small group in most countries. Also, as social democratic parties tried to appeal to younger, urban professionals, many industrial workers increasingly supported other parties (such as the populist right or radical left). This left social democrats relying increasingly on public sector employees. But, with the growing constraints on public spending after the Great Recession, this was no-longer a winning strategy. Can social democratic parties build a new electoral coalition? We leave this to others to answer, and hope our results and our dataset encourage new research in this area. 


\section{References}

Abou-Chadi, Tarik and Markus Wagner. 2019. "The Electoral Appeal of Party Strategies in Post-Industrial Societies: When Can the Mainstream Left Succeed?" Journal of Politics 4:1405-1419.

Adams, James. 2012. "The Causes and the Electoral Consequences of Party Policy Shifts in Multiparty Elections: Theoretical Results and Empirical Evidence." Annual Review of Political Science 15:401-419.

Bartolini, Stefano. 2000. Political Mobilization of the Europe Left 1860-1980: The Class Cleavage. Cambridge: Cambridge University Press.

Boix, Carles. 1985. Political Parties, Growth and Equality: Conservative and Social Democratic Economic Strategies in the World Economy. Cambridge: Cambridge University Press.

Boix, Carles. 1999. "Setting the Rules of the Game: The Choice of Electoral Systems in Advanced Democracies." American Political Science Review 93:609-624.

Borooah, Vani K. 1987. "The Growth of Public Expenditure in the United Kingdom, 196086." European Journal of Political Economy 3:493-521.

Carey, John M. and Simon Hix. 2011. "The Electoral Sweet Spot: Low-Magnitude Proportional Electoral Systems." American Journal of Political Science 55:383-397.

Colantone, Italo and Piero Stanig. 2018. "Global Competition and Brexit." American Political Science Review 112:201-218.

Crouch, Colin. 2017. "Membership Density and Trade Union Power." European Review of Labour and Research 23(1):47-61. 
Dinas, Elias et al. 2019. "Does Exposure to the Refugee Crisis Make Natives More Hostile?" American Political Science Review 113(2):442-455.

Dreher, Axel. 2006. "Does Globalization Affect Growth? Evidence from a new Index of Globalization." Applied Economics 38(10):1091-1110.

Eatwell, Roger and Matthew Goodwin. 2018. National Populism: The Revolt Against Liberal Democracy. London: Pelican Books.

Garrett, Geoffrey. 1998. Partisan Politics in the Global Economy. Cambridge: Cambridge University Press.

Giddens, Anthony. 1998. The Third Way: The Renewal of Social Democracy. London: Polity Press.

Gingrich, Jane and Silja Häusermann. 2015. "The Decline of the Working Class vote, the Reconfiguration of the Welfare Support Coalition and Consequences for the Welfare State." Journal of European Social Policy pp. 50-75.

Guiso, Luigi et al. 2019. "Global Crises and Populism: the Role of Eurozone Institutions." Economic Policy 38:95-139.

Gygli, Savina et al. 2019. "The KOF Globalisation Index - Revisited." Review of International Organizations 14:543?574.

Iversen, Torben and David Soskice. 2006. "Electoral Institutions and the Politics of Coalitions: Why Some Democracies Redistribute More Than Others." American Political Science Review 100:165-181.

Jacobs, Francis. 1989. Western European Political Parties: A Comprehensive Guide. London: Longman. 
Kaltwasser, Cristóbal Rovira et al. 2017. The Oxford Handbook of Populism. Oxford: Oxford University Press.

Kirchheimer, Otto. 1966. Political Parties and Political Development. Princeton: Princeton University Press chapter The Transformation of Western European Party Systems, pp. $177-200$.

Kitschelt, Herbert. 1990. The Transformation of European Social Democracy. Cambridge: Cambridge University Press.

Kriesi, Hanspeter et al. 2012. Political Conflict in Western Europe. Cambridge: Cambridge University Press.

Lipset, Seymor Martin. 1983. Political Man. The Social Bases of Politics. London: Heinemann.

Neisse, H. 1930. Sozialstatistischen Analyse des Wahlergebnisses.

Nohlen, Dieter and Philip Stoever. 2010. Elections in Europe: A Data Handbook. BadenBaden: Nomos.

Oesch, Daniel. 2006. Redrawing the Class Map: Stratification and Institutions in Britain, Germany, Sweden and Switzerland. Basingstoke: Palgrave Macmillan.

Piketty, Thomas. N.d. "Brahmin Left vs Merchant Right: Rising Inequality and the Changing Structure of Political Conflict (Evidence from France, Britain and the US, 1948-2017)." WID.world working paper series. Forthcoming.

Przeworski, Adam and John Sprague. 1986. Paper Stones: A History of Electoral Socialism. Chicago: University of Chicago Press. 
Sassoon, Donald. 1996. One Hundred Years of Socialism: The West European Left in the Twentieth Century. New York: New York Press.

Timmer, Marcel P. et al. 2015. Routledge Handbook of Industry and Development. London: Routledge chapter Patterns of Structural Change in Developing Countries, pp. 65-83.

von Beyme, Klaus. 1985. Political Parties in Western Democracies. New York: St. Martin's Press.

Wagner, Adolph. 1890. Finanzwissenschaft. Leipzig: Winter. 
The Rise and Fall of Social Democracy, 1918-2017 - Online Appendix 


\section{Appendix 1: Description of the Variables}

Centre Right economic left-right position: Economic left-right location of the main centre right competitor party in the year of the election, as measured by party manifesto coding. Source: Comparative Manifestos Project data, release 2016b (https://manifestoproject.wzb.eu).

Centre Right left-right position: Left-right location of the main centre right competitor party in the year of the election, as measured by party manifesto coding. Source: Comparative Manifestos Project data, release 2016b.

Centre Right social liberal-authority position: Social left-right location of the main centre right competitor party in the year of the election, as measured by party manifesto coding. Source: Comparative Manifestos Project data, release 2016b.

Centre Right vote share: Vote share of the centre right (conservative and Christian democratic) party/parties (percent) in the election. Source: Nohlen and Stoever (2010), plus national election commissions. We allocated parties to party families via their European and international party memberships and existing categorizations, in particular Von Beyme (1985), Jacobs (1989), and Hix and Lord (1997).

District magnitude (log): Natural log of the electoral system median district magnitude in the year of the election. Source: Boix (1999), Carey and Hix (2011), the Constituency-Level Election Archive (CLEA) (http://www.electiondataarchive.org), and estimated from the size of the legislature. 
Employment in agriculture (percent): Employment in agriculture (as a percent of total employment) in the year of the election. Source: World Bank Development Indicator, SL.AGR.EMPL.ZS

(http://data. worldbank.org/data-catalog/world-development-indicators).

Employment in industry (percent): Employment in industry (as a percent of total employment) in the year of the election. Source: World Bank Development Indicator, SL.IND.EMPL.ZS.

EU member: Country is a member of the ECSC, EEC, or EU in the year of the election. Source: European Union (https://europa.eu/european-union/about-eu/history_en).

Eurozone member: Country is a member of the Eurozone in the EU in the year of the election. Source: European Union (https://europa.eu/european-union/about-eu/history_en).

GDP growth: Annual Gross Domestic Product (GDP) in the year of the election. Source: Maddison Project data (http://www.ggdc.net/maddison/maddison-project/home.htm). Corrected to remove extreme outliers (less than -25 or greater than 25). Missing data entered from closest source, such as Penn World Tables (http://cid.econ.ucdavis.edu/pwt.html) or World Bank Development Indicator, or closest year in Maddison Project data.

GDP per capita (log): Natural log of GDP per capita in the year of the election. Source: Maddison Project Data (1990 Int. GK dollars). Missing data entered from closest source, such as Penn World Tables, or World Bank Development Indicator, or closest year 
in Maddison Project data.

Globalization index: KOG Globalization index (https://www.kof .ethz.ch/en/ forecasts-and-indicators/indicators/kof-globalisation-index.html). Source: Gygli et al. (2019).

Higher education: Gross enrollment ratio, tertiary, both sexes (percent) in the year of the election. Source: World Bank Development indicator, SE.TER.ENRR.

Inflation: Consumer price inflation (annual percent) in the year of the election. Source: World Bank Development Indicator, FP.CPI.TOTL.ZG.

Life expectancy: Life expectancy at birth, total (years) in the year of election. Source: World Bank Development indicator, SP.DYN.LE00.IN.

Manufacturing index: Index of manufacturing production (1953=100), which measures the volume of trade in manufactured goods in a country relative to 1953. Source: UN International Trade Statistics, 1900-1960.

Population: Natural log of total population in the year of the election. Source: World Bank Development indicator, SP.POP.TOTL.

Population aged 0 to 14: Population aged 0 to 14 (percent of the total) in the year of the election. Source: World Bank Development indicator, SP.POP.0014.TO.ZS.

Population aged 65 and over: Population aged 65 and older (percent of the total) in 
the year of the election. Source: World Bank Development indicator, SP.POP.65UP.TO.ZS.

Population growth: Population growth (annual percent change) in the year of the election. Source: World Bank Development indicator, SP.POP.GROW.

Post-tax inequality (GINI): Post-tax and spending income inequality in the year of the election, as measured by GINI coefficient. Source: Standardized World Income Inequality Database, version 5.1 (http://fsolt.org/swiid).

Public spending (percent of GDP): Government expenditure in the year of the election (as a percent of GDP). Source: combined from general government final consumption expenditure in the year of the election (as a percent of GDP) from the World Bank Development Indicator (GC.XPN.TOTL.GD.ZS) and government expenditure in the year of the election (as a percent of GDP) from Our World in Data (https://ourworldindata.org/public-spending).

SD economic left-right position: Economic left-right location of social democratic party in an election, as measured by party manifesto coding. Source: Comparative Manifestos Project data, release 2016b.

SD party in gov't (coalition-junior): coded 1 if (at the time of the election) the social democratic party is in a coalition government, but does not hold the Prime Minister position. Source:Nohlen and Stoever (2010), plus other available sources.

SD party in gov't (coalition-PM): coded 1 if (at the time of the election) the social democratic party is in a coalition government, and also holds the Prime Minister position. 
Source:Nohlen and Stoever (2010), plus other available sources.

SD party in gov't (single-party): coded 1 if (at the time of the election) the social democratic party is in government, and is the only party in the government. Source:Nohlen and Stoever (2010), plus other available sources.

SD social liberal-authority position: Social left-right location of the social democratic party in an election, as measured by party manifesto coding. Source: Comparative Manifestos Project data, release 2016b.

(Semi) Presidential system: Presidential, semi-presidential, or power-sharing regime in the year of the election. Source: Robert Elgie (http://www.semi (Semi)Presidentialism. com/?p=1053).

Share of industry in GDP: Share of the industrial sector in gross domestic product, measured in constant 2011 international-dollars. Source: Timmer et al. (2015).

Social Democrat left-right position: Left-right location of the social democratic party in an election, as measured by party manifesto coding. Source: Comparative Manifestos Project data, release 2016b.

Social Democratic party electorate share: Share of total electorate (percent) won by the social democratic party in the election. Source: Nohlen and Stoever (2010), plus national election commissions.

Social Democratic party vote share: Share of votes (percent) won by the social 
democratic party in the election. Source:Nohlen and Stoever (2010), plus national election commissions.

Total left vote share: Vote share of the social democrats and the radical/ other left party/parties (percent) in the election. Source: Nohlen and Stoever (2010), plus national election commissions.

Turnout: Turnout (percent) in the election. Source: Nohlen and Stoever (2010), plus national election commissions.

Unemployment: Unemployment in the year of the election, as a percent of the total labour force (modelled International Labor Organization (ILO) estimate. Source: World Bank Development Indicator, SL.UEM.TOTL.ZS.

Union density: Trade union density (measured as the percent of total wage earners who are trade union members) in the year of the election. Source: ICTWSS: Database on Institutional Characteristics of Trade Unions, Wage Setting, State Intervention and Social Pacts in 51 countries between 1960 and 2014 (http://www.uva-aias.net/en/ictwss).

Urban population: Urban population (as a percent of total population) in the year of the election. Source: World Bank Development indicator, SP.URB.TOTL.IN.ZS.

Women in work: Labour force participation rate, female (as a percent of the female population aged 15 or older), national estimate. Source: World Bank Development indicator, SL.TLF.CACT.FE.NE.ZS. 
Years of democracy: Number of years of continuous democracy in the year of the election (POLITY $\geqslant 7$, counted from year of first election, and then starting again at 1 following a period of a non-democracy. Source: Polity IV project (http://www.systemicpeace.org/polityproject.html).

Youth unemployment: Youth unemployment in the year of the election, as a percent of the labour force aged 15 to 24 (modelled ILO estimate). Source: World Bank Development Indicator, SL.UEM.1524.ZS. 


\section{Appendix 2: Supplementary Figures and Tables}

Figure A1: Vote shares of social democratic parties in Western Europe
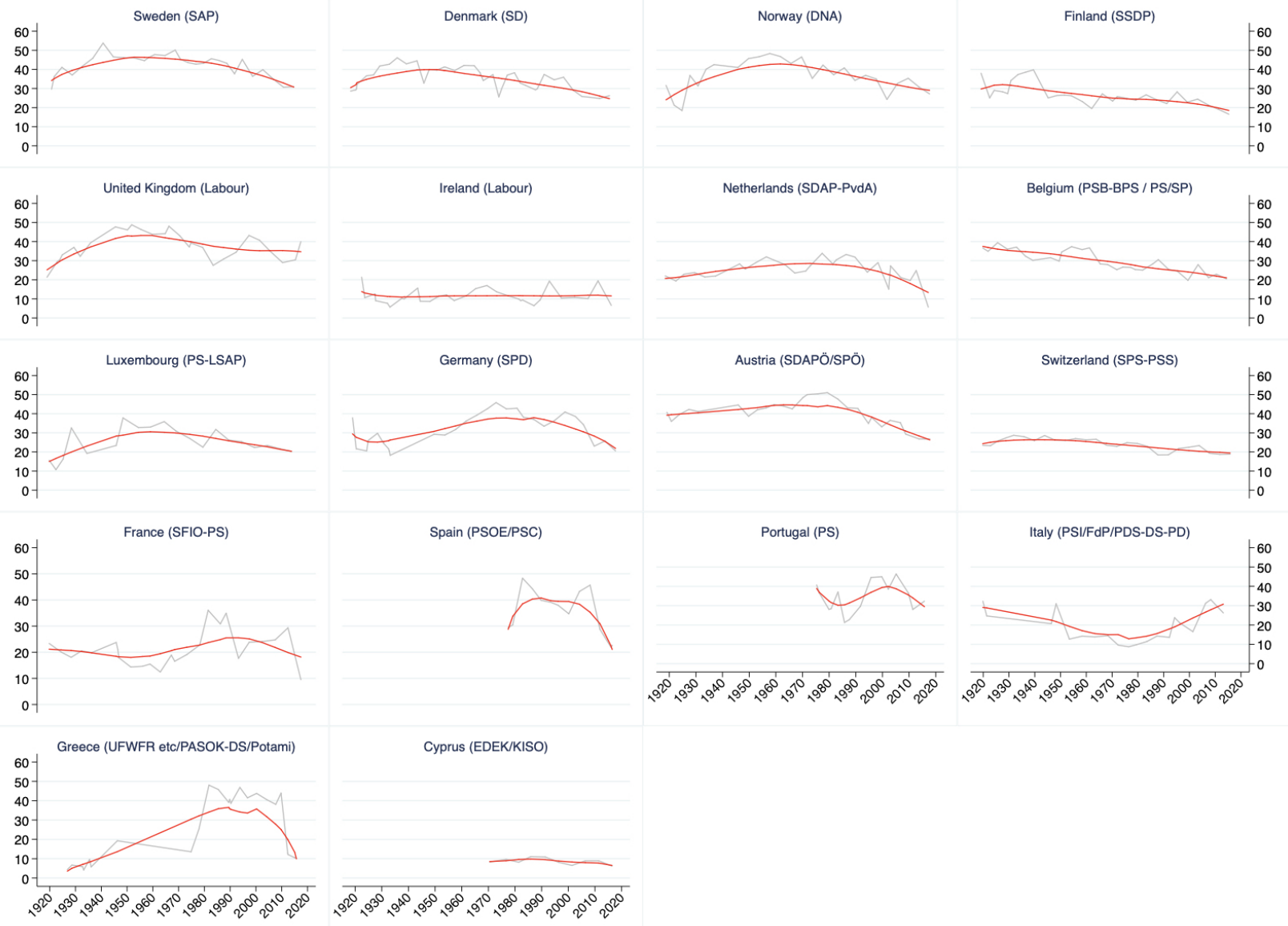

Note: The lines are estimated by locally weighted scatterplot smoothing. 
Figure A2: Vote shares of social democratic parties in Eastern Europe
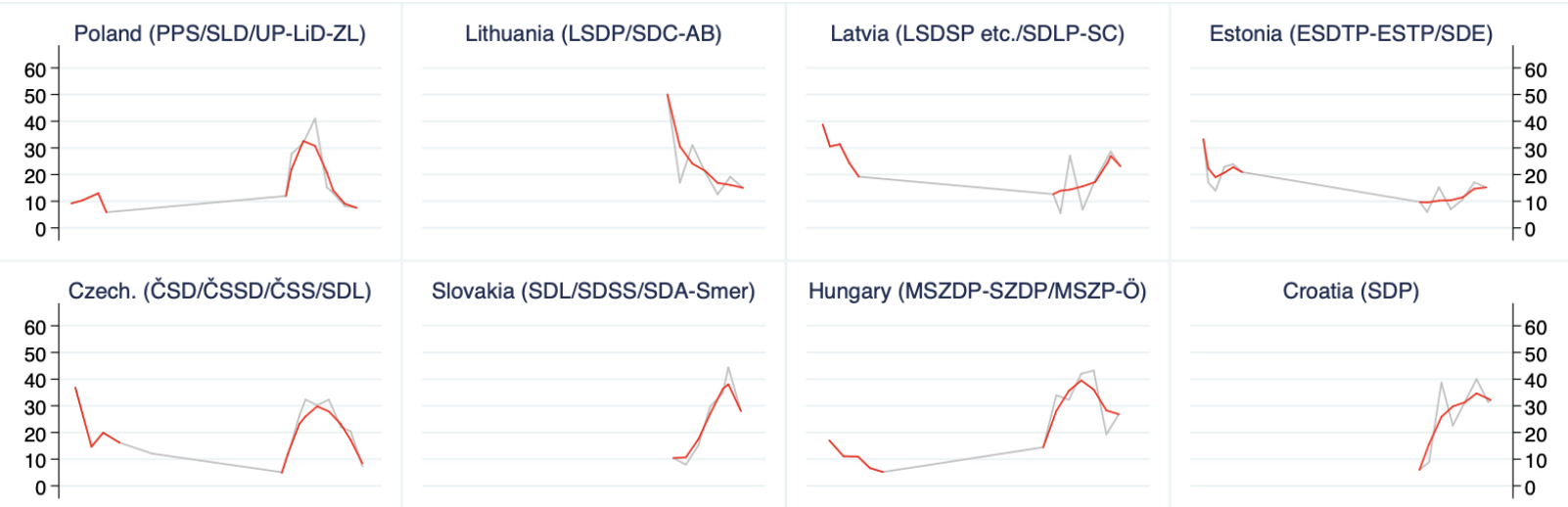

Croatia (SDP)
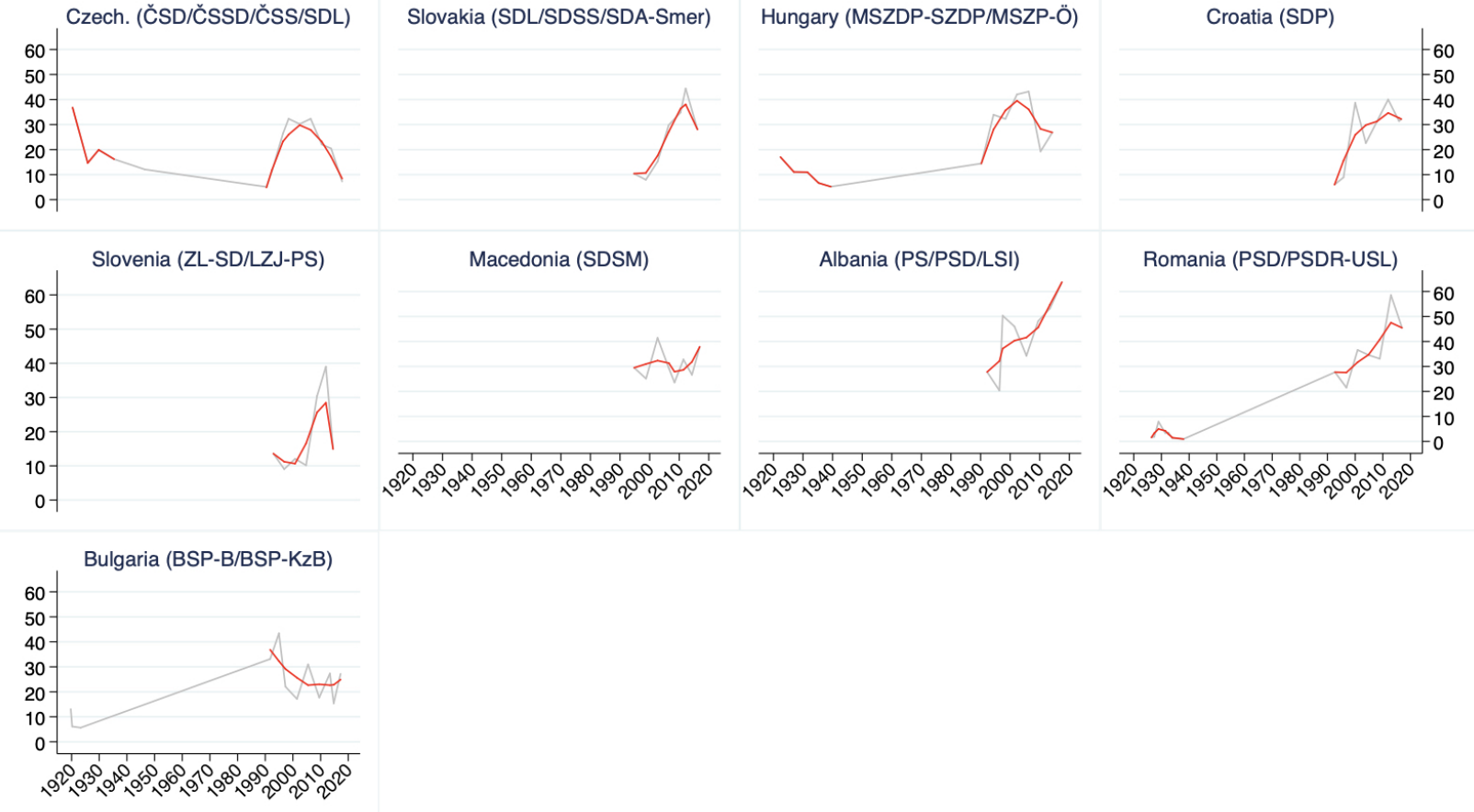

Note: The lines are estimated by locally weighted scatterplot smoothing. 
Figure A3: Vote shares of social democratic parties in 4 regions

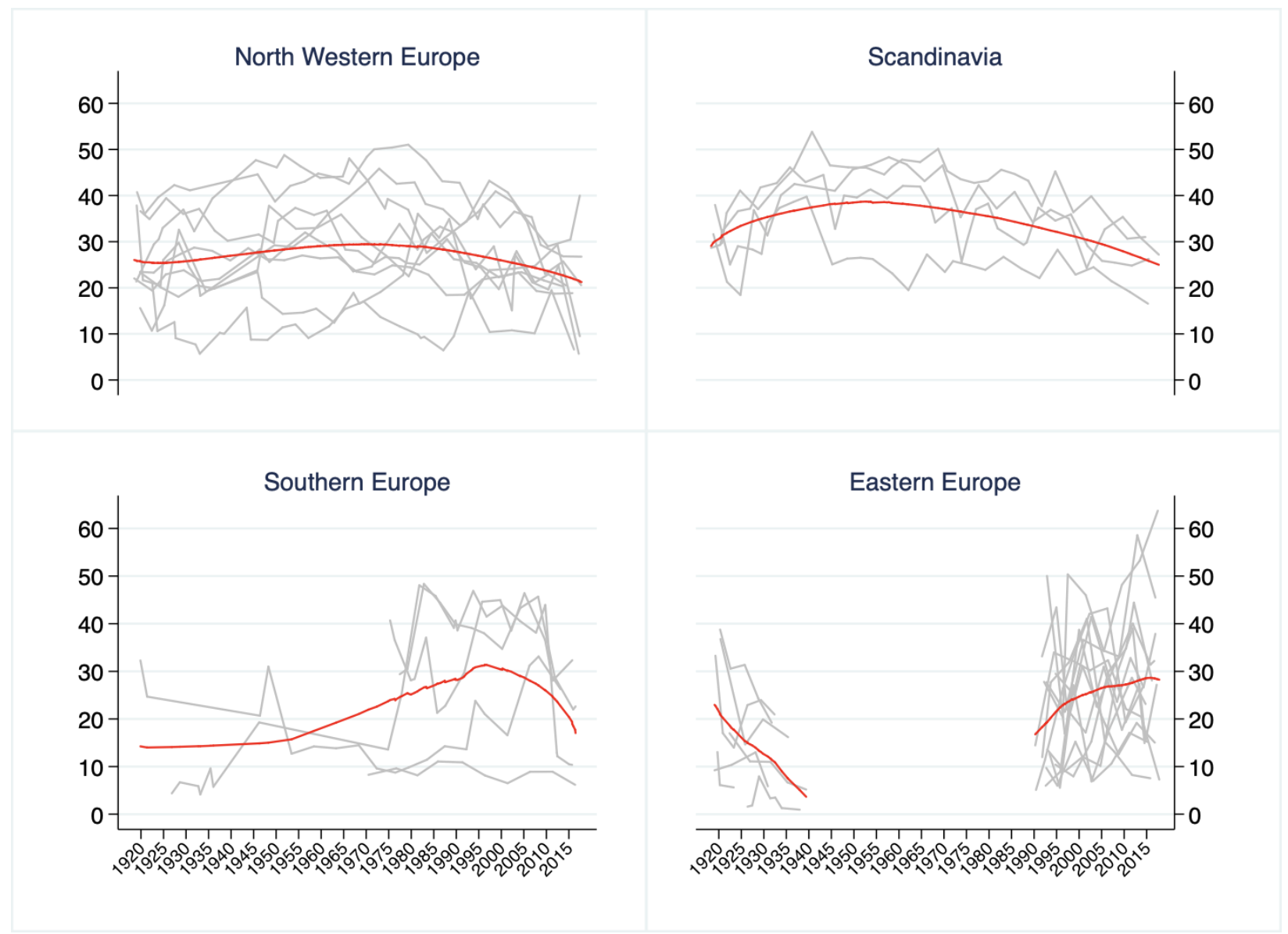

Note: The lines are estimated by locally weighted scatterplot smoothing. North Western Europe: Austria, Belgium, France,

Germany, Ireland, Luxembourg, Netherlands, Switzerland, United Kingdom. Scandinavia: Denmark, Finland, Norway,

Sweden. Southern Europe: Cyprus, Greece, Italy, Portugal, Spain. Eastern Europe: Albania, Bulgaria, Croatia,

Czechoslovakia/Czech Republic, Estonia, Hungary, Latvia, Lithuania, Macedonia, Poland, Romania, Slovakia, Slovenia. 


\section{Table A2: Cases of social democratic parties}

\begin{tabular}{|c|c|c|}
\hline Country & Abbr & Name \\
\hline Albania & PS & Partia Socialiste e Shqipërisë \\
\hline Albania & PSD & Partia Socialdemokrate e Shqipërisë \\
\hline Albania & LSI & Lëvizja Socialiste për Integrim \\
\hline Austria & SDAPÖ & Sozialdemokratische Arbeiterpartei Österreichs \\
\hline Austria & SPÖ & Sozialistische/Sozialdemokratische Partei Österreichs \\
\hline Belgium & BWP/POB & Parti Ouvrier Belge/Belgische Werkliedenpartij \\
\hline Belgium & PSB/BSP & Parti socialiste Belge/Belgische Socialistische Partij \\
\hline Belgium & PS & Parti socialiste \\
\hline Belgium & $\mathrm{SP} / \mathrm{SPa}$ & Socialistische Partij/ Socialistische Partij Anders \\
\hline Bulgaria & BSP-B & Balgarska rabotnicheska sotsialdemokraticheska partia (shiroki sotsialisti) \\
\hline Bulgaria & $\mathrm{BSP} / \mathrm{Kz} \mathrm{B}$ & Bulgarska sotsialisticheska partiya / Koalitsiya za Bulgaria \\
\hline Croatia & SDP & Socjialdemokratska partija Hrvatske \\
\hline cyprus & EDEK/KISOS & Kinima Sosialdimokraton Eniaia Dimokratiki Enosi Kentrou / Kinima Sosialdimokraton \\
\hline Czechoslovakia/Czech Republic & ČSDSD/ČSD & Československá sociálnē-demokratická dělnická / Československá sociälni demokracie \\
\hline Czechoslovakia/Czech Republic & DSDAP & Deutsche sozialdemokratische Arbeiterpartei in der Tschechoslowakischen Republik \\
\hline & & Sociálni demokracie / Československá strana sociálnĕ demokratická / Česká strana sociál \\
\hline Czechoslovakia/Czech Republic & SD / ČSSD & demokratická \\
\hline Czechoslovakia/Czech Republic & čss & Československá strana socialistická \\
\hline Czechoslovakia/Czech Republic & SDL & Strana demokratickej lavice \\
\hline Denmark & SD & Socialdemokratiet \\
\hline Estonia & ESDTP / ESTP & Eesti Sotsiaaldemokraatiline Tööliste Partei / Eesti Sotsialistlik Tööliste Partei \\
\hline Estonia & SDE & Sotsiaaldemokraatilik Erakond \\
\hline Finland & SSDP & Suomen Sosialidemokraattinen Puolue \\
\hline France & SFIO & Section Française de l'Internationale Ouvrière \\
\hline France & FGDS & Fédération de la gauche démocrate et socialiste \\
\hline France & PS & Parti socialiste \\
\hline Germany & SPD & Sozialdemokratische Partei Deutschlands \\
\hline Greece & UFWFR & United Front of Workers, Farmers and Refugees \\
\hline Greece & ALP & Agricultural and Labour Party \\
\hline Greece & APF & All People Front \\
\hline Greece & NPU & National Political Union \\
\hline Greece & PASOK/DS & Panellinio Sosisalistiko Kinima Ellados / Dimokratiki Symparataxi \\
\hline Greece & Potami & To Potami \\
\hline Hungary & MSZDP/SZDP & P Magyarországi Szociáldemokrata Párt/ Szociáldemokrata Párt \\
\hline Hungary & MSZP & Magyar Szocialista Párt \\
\hline Hungary & ö & Összefogás \\
\hline Ireland & Lab & Labour Party \\
\hline Italy & PSI & Partito Socialista Italiano / Partito Socialista Unificato (1968) \\
\hline Italy & FdP & Fronte del Popolo (PCI+PSI) \\
\hline Italy & $\mathrm{PC} / \mathrm{PDS} / \mathrm{DS}$ & Partito Democratico della Sinistra / Dem cratici di Sinistra \\
\hline Italy & Ulivo/PD & L'Ulivo/ Partito Democratico \\
\hline Latvia & LSDSP & Latvijas Sociäldemokrătiskā Strādnieku Partija \\
\hline Latvia & SLAT/TSP & Saskana Latvijai - Atdzimšana Tautsaimniecibai / Tautas Saskananas partija \\
\hline Latvia & SDS / SDP & Sociäldemokrâtu savieniba / Socialddemokrātiskā partija \\
\hline Latvia & SDLP & Sociâldemokrātiskā Labklājlbas partija \\
\hline Latvia & SC/SDPS & Saskanas Centrs / Socialddemokrātiskā Partija "Saskana" \\
\hline Lithuania & LSDP & Lietuvos socialdemokraty partija \\
\hline Lithuania & LDDP & Lietuvos demokratinè darbo partija \\
\hline Lithuania & SDC-AB & Social-Democratic Coalition of Algirdas Brazauskas \\
\hline Luxembourg & PS/ LSAP & Parti socialiste / Lëtzebuerger Sozialistesch Aarbechterpartei \\
\hline Macedonia & SDSM & Socjalddemokratski sojuz na Makedonija \\
\hline Netherlands & SDAP & Sociaal Demcratische Arbeiders Partij \\
\hline Netherlands & PvdA & Partij van de Arbeid \\
\hline Norway & DNA & Det norske Arbeiderpartei \\
\hline Poland & PPS & Polska Partia Socjalistyczna \\
\hline Poland & SLD & Sojusz Lewicy Demokratycznej \\
\hline Poland & up & Unia Pracy \\
\hline Poland & LID & Lewica i Demokraci \\
\hline Poland & $\mathrm{zL}$ & Zjednoczona Lewica \\
\hline Portugal & PS & Partido Socialista \\
\hline Romania & FPSR & Federația Partidelor Socialiste din România \\
\hline Romania & PSD & Partidul Social Democrat \\
\hline Romania & FDSN & Frontul Democrat al Salvării Nationale \\
\hline Romania & PSDR & Partidul Social Democrat Român \\
\hline Romania & USL & Uniunea Social Liberală \\
\hline Slovakia & SDL & Strana demokratickej lavice \\
\hline Slovakia & sDss & Sociálnodemokratická strana Slovenska \\
\hline Slovakia & Smer & Smer-sociálna demokracia \\
\hline Slovakia & SDA & Sociálnodemokratická altemativa \\
\hline Slovenia & $\mathrm{ZL} / \mathrm{SD}$ & Združena lista socialnin demokratov / Socialni demokrati \\
\hline Slovenia & LuJ.PS & Lista Zorana Jankovića - Pozitivna Slovenija \\
\hline Slovenia & $\mathrm{zL}$ & Združena levica \\
\hline Spain & PSOE & Partido Socialista Obrero Español \\
\hline Spain & PSC & Partit dels Socialistes de Catalunya \\
\hline Sweden & SAP & Sveriges socialdemokratiska arbetareparti \\
\hline Switzerland & SPS/PSS & Sozialdemokratische Partei der Schweiz/Parti socialiste suisse/Partito Socialista Svizzero \\
\hline United Kingdom & Lab & Labour Party \\
\hline
\end{tabular}

\begin{tabular}{|c|c|}
\hline English name & Years \\
\hline Socialist Party of Albania & 1992-2017 \\
\hline Social Democratic Party of Albania & 1992-2017 \\
\hline Socialist Movement for Integration & 2004-2017 \\
\hline Social Democratic Workers' Party of Austria & 1918-1945 \\
\hline Social ist/Social Democratic Party of Austria & 1945-2017 \\
\hline Belgian Labour Party & 1918-1945 \\
\hline Belgian Socialist Party & 1945-1978 \\
\hline Socialist Party (Wallonia) & 1978-2017 \\
\hline Socialist Party / Socialist Party Differently (Flanders) & 1978-2017 \\
\hline Bulgarian Social Democratic Workers Party (Broad Socialists) & 1919-1923 \\
\hline Bugarian Socialist Party / Coalition for Bulgaria & 1991-2017 \\
\hline Social Democratic Party of Croatia & 1992-2017 \\
\hline Movement of Social Democrats / Social Democrats Movement & 1960-2017 \\
\hline Crechoslovak Social Democratic Workers Party / Czechoslovak Social Democracy / Czechos & \\
\hline Czech Social Democratic Party & 1920-1946 \\
\hline German Social Democratic Workers' Party in the Czechoslovak Republic & 1920-1938 \\
\hline Social Democracy / Crechoslovak Social Democratic Party / Crech Social Democratic Party & 1990-2017 \\
\hline Czechoslovak Socialist Party & 1990-1991 \\
\hline Party of the Democratic Left & 1992-1995 \\
\hline Social Democrats & 1918-2017 \\
\hline Estonian Social Democratic Workers' Party / Estonian Social list Workers' Party & 1918-1933 \\
\hline Social Democratic Party & 1992-2017 \\
\hline Social Democratic Party of Finland & 1918-2017 \\
\hline French Section of the Socialist International & 1918-1965 \\
\hline Federation of the Democratic and Socialist Left & $1965-1969$ \\
\hline Socialist Party & 1969-2017 \\
\hline Social Democratic Party of Germany & 1918-2017 \\
\hline United Front of Workers, Farmers and Refugees & 1926-1927 \\
\hline Agricultural and Labour Party & 1928-1934 \\
\hline All People Front & $1935-1945$ \\
\hline National Political Union & $1946-1948$ \\
\hline Pan-Hellenic Socialist Movement / Democratic Alignment & 1974-2017 \\
\hline The River & 2015-2017 \\
\hline Hungarian Social Democratic Party / Social Democratic Party & 1920-1994 \\
\hline Hungarian Socialist Party & 1989-2013 \\
\hline Unity & 2014-2017 \\
\hline Labour Party & 1918-2017 \\
\hline Italian Socialist Party / Unified Socialist Party & 1918-1947, \\
\hline People's Front & 1948-1952 \\
\hline Democratic Party of the Left/ Democrats of the Left & $1967-2005$ \\
\hline The Olive Tree / Democratic Party & 2006-2017 \\
\hline Latvian Social Democratic Workers' Party & 1920-2017 \\
\hline Harmony for Latvia / National Harmony Party (of Russian minority) & 1990-1994 \\
\hline Social Democratic Union / Social Democratic Party & $2002-2005$ \\
\hline Social Democratic Welfare Party & $2002-2005$ \\
\hline Harmony Centre / Social Democratic Party "Harmony" & 2006-2017 \\
\hline Social Democratic Party of Lithuania & 1991-2017 \\
\hline Democratic Labour Party of Lithuania & $1991-2003$ \\
\hline Social-Democratic Coalition of Algirdas Brazauskas & 2000-2003 \\
\hline Socialist Party / Luxembourg Socialist Workers' Party & 1918-2017 \\
\hline Social Democratic Union of Macedonia & $1990-2017$ \\
\hline Social Democratic Workers' Party & 1918-1945 \\
\hline Labour Party & $1946-2017$ \\
\hline Labour Party & 1918-2017 \\
\hline Polish Socialist Party & 1919-1928 \\
\hline Democratic Left Alliance & $1990-2017$ \\
\hline Labour Union & $1993-2006$ \\
\hline Left and Democrats & $2007-2010$ \\
\hline United Left & 2015-2017 \\
\hline Socialist Party & $1975-2017$ \\
\hline Federation of Socialist Parties from Romania & 1926-1927 \\
\hline Social Democratic Party & $1928-1948$ \\
\hline Democratic National Salvation Front & $1992-2005$ \\
\hline Romanian Social Democratic Party & $1996-2011$ \\
\hline Social Liberal Union & 2012-2017 \\
\hline Party of the Democratic Left & 1993-2005 \\
\hline Social Democratic Party of Slovakia & 1993-2005 \\
\hline Direction Social Democracy & 2002-2017 \\
\hline Social Democatic Alternative & 2002-2005 \\
\hline United List of Social Democrats / Social Democrats & 1992-2017 \\
\hline Zoran Janković's List - Positive Slovenia & 2011-2013 \\
\hline United Left & 2014-2017 \\
\hline Spanish Soclialist Workers' Party & $1977-2008$ \\
\hline Party of the Socialists of Catalunya & $1977-2008$ \\
\hline Social Democratic Workers' Party & 1918-2017 \\
\hline Social Democratic/Socialist Party of Switzerland & $1918-2017$ \\
\hline Labour Party & 1918-2017 \\
\hline
\end{tabular}


Table A3: Correlates of social democratic party vote shares, 1945-2017

\begin{tabular}{|c|c|c|c|c|}
\hline & \multicolumn{2}{|c|}{ Analysis of levels } & \multicolumn{2}{|c|}{ Analysis of differences } \\
\hline & $(1)$ & $(2)$ & $(3)$ & $(4)$ \\
\hline \multirow[t]{2}{*}{ Public Spending (\% of GDP) } & $0.157^{* *}$ & $0.193^{* * *}$ & $0.168^{* *}$ & $0.163^{* *}$ \\
\hline & $(0.058)$ & $(0.059)$ & $(0.073)$ & $(0.073)$ \\
\hline \multirow[t]{2}{*}{ Social Democrat left-right position } & $0.172^{* *}$ & $0.170^{*}$ & $0.148^{* *}$ & $0.150^{* *}$ \\
\hline & $(0.081)$ & $(0.084)$ & $(0.068)$ & $(0.069)$ \\
\hline \multirow[t]{2}{*}{ Centre Right left-right position } & -0.003 & -0.003 & -0.036 & -0.036 \\
\hline & $(0.036)$ & $(0.035)$ & $(0.030)$ & $(0.030)$ \\
\hline \multirow[t]{2}{*}{ District Magnitude } & 0.574 & 0.787 & 0.948 & 0.912 \\
\hline & $(1.292)$ & $(1.308)$ & $(1.596)$ & $(1.581)$ \\
\hline \multirow[t]{2}{*}{ District mag. ${ }^{*}$ SD left-right position } & $-0.058^{*}$ & $-0.055^{*}$ & $-0.061^{* *}$ & $-0.062^{* *}$ \\
\hline & $(0.030)$ & $(0.032)$ & $(0.027)$ & $(0.027)$ \\
\hline \multirow[t]{2}{*}{ SD party in gov't (single-party) } & 1.335 & 1.097 & $-3.175^{* * *}$ & $-3.187^{* * *}$ \\
\hline & $(1.256)$ & $(1.230)$ & $(0.957)$ & $(0.962)$ \\
\hline \multirow[t]{2}{*}{ SD party in gov't (coalition-PM) } & 0.976 & 0.634 & $-2.507^{* *}$ & $-2.506^{* *}$ \\
\hline & $(1.327)$ & $(1.285)$ & $(0.963)$ & $(0.966)$ \\
\hline \multirow[t]{2}{*}{ SD party in gov't (coalition-junior) } & $-2.849^{* * *}$ & $-3.056^{* * *}$ & $-2.461^{* * *}$ & $-2.451^{* * *}$ \\
\hline & $(0.912)$ & $(0.925)$ & $(0.721)$ & $(0.721)$ \\
\hline \multirow[t]{2}{*}{ Turnout } & -0.084 & -0.086 & $0.300^{* *}$ & $0.299^{* *}$ \\
\hline & $(0.106)$ & $(0.101)$ & $(0.130)$ & $(0.129)$ \\
\hline \multirow[t]{2}{*}{ GDP per capita (Madison) } & 3.577 & 5.310 & 2.008 & 2.447 \\
\hline & $(2.877)$ & $(3.238)$ & $(2.969)$ & $(2.910)$ \\
\hline \multirow[t]{2}{*}{ GDP growth (Madison) } & -0.097 & -0.057 & -0.166 & -0.167 \\
\hline & $(0.138)$ & $(0.145)$ & $(0.224)$ & $(0.225)$ \\
\hline \multirow[t]{2}{*}{ EU member } & -1.136 & -0.385 & -1.283 & -1.052 \\
\hline & $(2.055)$ & $(2.055)$ & $(1.476)$ & $(1.572)$ \\
\hline \multirow[t]{2}{*}{ Eurozone member } & 2.646 & 2.848 & -0.082 & -0.021 \\
\hline & $(2.182)$ & $(2.112)$ & $(1.335)$ & $(1.307)$ \\
\hline \multirow[t]{2}{*}{ Presidential system } & $11.214^{* *}$ & $10.644^{* *}$ & 2.444 & 2.463 \\
\hline & $(4.179)$ & $(3.886)$ & $(4.763)$ & $(4.777)$ \\
\hline Country fixed effects & Yes & Yes & Yes & Yes \\
\hline Decade fixed effects & Yes & Yes & Yes & Yes \\
\hline Country-year effects & No & Yes & No & Yes \\
\hline Observations & 381 & 381 & 353 & 353 \\
\hline R-squared & 0.162 & 0.176 & 0.169 & 0.170 \\
\hline Number of countries & 31 & 31 & 31 & 31 \\
\hline
\end{tabular}

Note: Dependent variable: social democratic party vote share. Models 1 and 2 estimate effects on the overall level of support for social democratic parties. Models 3 and 4 estimate changes in support between elections (first differences). Standard errors in parentheses. 
Table A4: Correlates of Social Democratic votes in the era of globalization, 1975-2017

\begin{tabular}{|c|c|c|c|c|c|c|c|c|}
\hline & \multicolumn{4}{|c|}{ Analysis of levels } & \multicolumn{4}{|c|}{ Analysis of differences } \\
\hline & (1) & $(2)$ & (3) & (4) & $(5)$ & (6) & $(7)$ & $(8)$ \\
\hline \multirow[t]{2}{*}{ Public Spending ( $\%$ of GDP) } & $0.249^{*}$ & $0.222^{*}$ & & & $0.229^{* *}$ & 0.206 & & \\
\hline & $(0.129)$ & $(0.122)$ & & & $(0.110)$ & $(0.125)$ & & \\
\hline \multirow[t]{2}{*}{ Welfare spending (\% GDP) } & & & $0.509^{* *}$ & $0.532^{* *}$ & & & $0.839^{* *}$ & $0.864^{* *}$ \\
\hline & & & $(0.243)$ & $(0.239)$ & & & $(0.318)$ & $(0.327)$ \\
\hline \multirow[t]{2}{*}{ Employment in industry (\%) } & $0.981^{* * *}$ & $0.866^{* * *}$ & $0.970^{* *}$ & $0.862^{* *}$ & 0.147 & 0.167 & 0.224 & 0.207 \\
\hline & $(0.277)$ & $(0.274)$ & $(0.348)$ & $(0.324)$ & $(0.327)$ & $(0.330)$ & $(0.334)$ & $(0.323)$ \\
\hline \multirow[t]{2}{*}{ Globalization Index } & 0.027 & 0.036 & 0.251 & 0.226 & 0.210 & 0.179 & 0.411 & 0.431 \\
\hline & $(0.350)$ & $(0.345)$ & $(0.451)$ & $(0.428)$ & $(0.473)$ & $(0.477)$ & $(0.365)$ & $(0.378)$ \\
\hline \multirow{2}{*}{ Social Democrat left-right position } & $0.102^{* *}$ & $0.100^{* *}$ & 0.046 & 0.049 & 0.029 & 0.032 & 0.040 & 0.040 \\
\hline & $(0.048)$ & $(0.048)$ & $(0.034)$ & $(0.035)$ & $(0.038)$ & $(0.039)$ & $(0.026)$ & $(0.026)$ \\
\hline \multirow[t]{2}{*}{ Centre Right left-right position } & -0.006 & -0.008 & 0.062 & 0.049 & -0.051 & -0.050 & -0.024 & -0.024 \\
\hline & $(0.051)$ & $(0.051)$ & $(0.053)$ & $(0.055)$ & $(0.043)$ & $(0.042)$ & $(0.036)$ & $(0.037)$ \\
\hline \multirow[t]{2}{*}{ SD party in gov't (single-party) } & -0.347 & -0.598 & -0.148 & -0.524 & $-3.523^{* *}$ & $-3.456^{* *}$ & $-3.908^{* *}$ & $-3.954^{* *}$ \\
\hline & $(1.451)$ & $(1.431)$ & $(1.826)$ & $(1.806)$ & $(1.393)$ & $(1.397)$ & $(1.428)$ & $(1.407)$ \\
\hline \multirow[t]{2}{*}{ SD party in gov't (coalition-PM) } & -0.936 & -0.791 & -1.002 & -1.001 & $-3.651^{* * *}$ & $-3.583^{* * *}$ & $-4.516^{* * *}$ & $-4.579^{* * *}$ \\
\hline & $(1.435)$ & $(1.460)$ & $(1.304)$ & $(1.302)$ & $(1.093)$ & $(1.110)$ & $(1.007)$ & $(1.027)$ \\
\hline \multirow[t]{2}{*}{ SD party in gov't (coalition-junior) } & $-3.214^{* *}$ & $-3.233^{* *}$ & $-4.703^{* * *}$ & $-5.031^{* * *}$ & $-3.705^{* * *}$ & $-3.714^{* * *}$ & $-5.843^{* * *}$ & $-5.837 * * *$ \\
\hline & $(1.348)$ & $(1.348)$ & $(1.314)$ & $(1.303)$ & $(1.028)$ & $(1.029)$ & $(1.152)$ & $(1.157)$ \\
\hline \multirow[t]{2}{*}{ Turnout } & 0.121 & 0.100 & 0.072 & 0.038 & $0.313^{*}$ & $0.309^{*}$ & -0.003 & -0.000 \\
\hline & $(0.148)$ & $(0.139)$ & $(0.157)$ & $(0.142)$ & $(0.171)$ & $(0.167)$ & $(0.208)$ & $(0.207)$ \\
\hline \multirow[t]{2}{*}{ Union density } & -0.197 & -0.184 & $-0.457^{* *}$ & $-0.442^{* *}$ & -0.113 & -0.106 & $-0.454^{*}$ & $-0.456^{*}$ \\
\hline & $(0.133)$ & $(0.132)$ & $(0.191)$ & $(0.182)$ & $(0.147)$ & $(0.144)$ & $(0.241)$ & $(0.245)$ \\
\hline \multirow[t]{2}{*}{ Higher education } & -0.057 & -0.017 & -0.052 & 0.014 & -0.040 & -0.039 & -0.177 & -0.175 \\
\hline & $(0.074)$ & $(0.079)$ & $(0.088)$ & $(0.097)$ & $(0.129)$ & $(0.126)$ & $(0.131)$ & $(0.131)$ \\
\hline \multirow[t]{2}{*}{ Life Expectancy } & $2.500^{* * *}$ & $2.769^{* * *}$ & 0.850 & $1.573^{* *}$ & 1.916 & 1.827 & -1.289 & -1.310 \\
\hline & $(0.707)$ & $(0.714)$ & $(0.639)$ & $(0.585)$ & $(1.241)$ & $(1.221)$ & $(1.575)$ & $(1.570)$ \\
\hline \multirow[t]{2}{*}{ District magnitude (\%) } & $2.033^{*}$ & $1.922^{*}$ & $1.835^{* *}$ & $1.667 * * *$ & 1.071 & 1.053 & 1.247 & 1.233 \\
\hline & $(1.166)$ & $(1.051)$ & $(0.667)$ & $(0.583)$ & $(1.270)$ & $(1.219)$ & $(0.851)$ & $(0.836)$ \\
\hline \multirow[t]{2}{*}{ Employment in agriculture } & $0.490^{*}$ & 0.394 & 0.543 & 0.479 & 0.116 & 0.135 & $-1.072^{* *}$ & $-1.102^{* *}$ \\
\hline & $(0.272)$ & $(0.259)$ & $(0.583)$ & $(0.516)$ & $(0.306)$ & $(0.315)$ & $(0.461)$ & $(0.481)$ \\
\hline \multirow[t]{2}{*}{ Women in work } & 0.072 & 0.087 & -0.035 & -0.010 & -0.062 & -0.078 & -0.218 & -0.214 \\
\hline & $(0.161)$ & $(0.155)$ & $(0.138)$ & $(0.131)$ & $(0.168)$ & $(0.172)$ & $(0.217)$ & $(0.223)$ \\
\hline \multirow[t]{2}{*}{ Urban population } & -0.070 & -0.030 & -0.220 & -0.125 & -0.324 & -0.336 & -0.623 & -0.624 \\
\hline & $(0.228)$ & $(0.231)$ & $(0.256)$ & $(0.248)$ & $(0.608)$ & $(0.615)$ & $(0.459)$ & $(0.449)$ \\
\hline \multirow[t]{2}{*}{ Population (log) } & -5.476 & -6.076 & 16.241 & 11.144 & -36.827 & -45.650 & -10.967 & -6.510 \\
\hline & $(12.266)$ & $(11.672)$ & $(17.767)$ & $(15.900)$ & $(46.721)$ & $(47.695)$ & $(47.187)$ & $(48.821)$ \\
\hline \multirow[t]{2}{*}{ Population aged 65 and over } & 0.261 & 0.398 & 0.939 & 0.999 & -1.306 & -1.330 & -1.197 & -1.210 \\
\hline & $(0.955)$ & $(0.953)$ & $(0.923)$ & $(0.908)$ & $(0.793)$ & $(0.836)$ & $(0.971)$ & $(0.982)$ \\
\hline Population aged 0 to 14 & -0.018 & -0.060 & 0.380 & 0.285 & 1.499 & 1.575 & 1.605 & 1.529 \\
\hline & $(0.537)$ & $(0.554)$ & $(0.560)$ & $(0.629)$ & $(1.047)$ & $(1.070)$ & $(1.056)$ & $(1.103)$ \\
\hline Country fixed-effects & Yes & Yes & Yes & Yes & Yes & Yes & Yes & Yes \\
\hline Decade fixed-effects & Yes & Yes & Yes & Yes & Yes & Yes & Yes & Yes \\
\hline Country-year effects & No & Yes & No & Yes & No & Yes & No & Yes \\
\hline Observations & 244 & 244 & 193 & 193 & 227 & 227 & 171 & 171 \\
\hline R-squared & 0.223 & 0.240 & 0.308 & 0.335 & 0.234 & 0.239 & 0.343 & 0.344 \\
\hline Number of countries & 27 & 27 & 22 & 22 & 27 & 27 & 22 & 22 \\
\hline
\end{tabular}

Note: Dependent variable: social democratic party vote share. Models 1, 2, 3, and 4 estimate effects on the overall level of support for social democratic parties. Models 5, 6, 7, and 8 estimate changes in support between elections (first differences). 
Table A5: Correlates of Social Democratic votes in the era of globalization, 1989-2017

\begin{tabular}{|c|c|c|c|c|c|c|c|c|}
\hline & \multicolumn{4}{|c|}{ Analysis of levels } & \multicolumn{4}{|c|}{ Analysis of differences } \\
\hline & (1) & $(2)$ & (3) & $(4)$ & $(5)$ & (6) & $(7)$ & $(8)$ \\
\hline \multirow[t]{2}{*}{ Public Spending (\% of GDP) } & 0.269 & 0.223 & & & $0.281^{*}$ & $0.267^{*}$ & & \\
\hline & $(0.166)$ & $(0.153)$ & & & $(0.139)$ & $(0.142)$ & & \\
\hline \multirow[t]{2}{*}{ Welfare spending (\% GDP) } & & & $0.815^{* *}$ & $0.750^{* *}$ & & & $0.893^{* *}$ & $0.918^{* *}$ \\
\hline & & & $(0.385)$ & $(0.353)$ & & & $(0.392)$ & $(0.382)$ \\
\hline \multirow[t]{2}{*}{ Employment in industry (\%) } & $0.628 *$ & 0.462 & $1.265^{* *}$ & $1.019 * *$ & -0.206 & -0.207 & 0.573 & 0.588 \\
\hline & $(0.338)$ & $(0.375)$ & $(0.462)$ & $(0.488)$ & $(0.345)$ & $(0.343)$ & $(0.398)$ & $(0.408)$ \\
\hline \multirow[t]{2}{*}{ Globalization Index } & 0.373 & 0.438 & 0.534 & 0.711 & -0.035 & -0.031 & 0.300 & 0.283 \\
\hline & $(0.424)$ & $(0.423)$ & $(0.475)$ & $(0.441)$ & $(0.556)$ & $(0.556)$ & $(0.464)$ & $(0.460)$ \\
\hline \multirow{2}{*}{ Social Democrat left-right position } & $0.135^{*}$ & $0.139^{*}$ & 0.054 & 0.059 & 0.024 & 0.028 & 0.019 & 0.017 \\
\hline & $(0.072)$ & $(0.070)$ & $(0.053)$ & $(0.050)$ & $(0.055)$ & $(0.056)$ & $(0.047)$ & $(0.047)$ \\
\hline \multirow[t]{2}{*}{ Centre Right left-right position } & 0.008 & 0.009 & 0.069 & 0.060 & -0.054 & -0.055 & 0.000 & 0.001 \\
\hline & $(0.052)$ & $(0.052)$ & $(0.056)$ & $(0.060)$ & $(0.048)$ & $(0.048)$ & $(0.048)$ & $(0.048)$ \\
\hline \multirow[t]{2}{*}{ SD party in gov't (single-party) } & -2.967 & -3.211 & -2.371 & -3.010 & $-4.958^{* * *}$ & $-5.046^{* * *}$ & $-4.183^{* *}$ & $-4.099^{*}$ \\
\hline & $(2.005)$ & $(2.078)$ & $(2.145)$ & $(2.501)$ & $(1.705)$ & $(1.698)$ & $(1.996)$ & $(2.016)$ \\
\hline \multirow[t]{2}{*}{ SD party in gov't (coalition-PM) } & -0.368 & -0.492 & 0.307 & 0.033 & $-4.042^{* * *}$ & $-4.053^{* * *}$ & $-3.780^{* * *}$ & $-3.793^{* * *}$ \\
\hline & $(1.444)$ & $(1.432)$ & $(1.034)$ & $(1.088)$ & $(1.177)$ & $(1.175)$ & $(1.320)$ & $(1.327)$ \\
\hline \multirow[t]{2}{*}{ SD party in gov't (coalition-junior) } & $-3.425^{*}$ & $-3.497^{*}$ & $-4.609 * *$ & $-4.983^{* *}$ & $-4.516^{* * *}$ & $-4.545^{* * *}$ & $-5.468^{* * *}$ & $-5.470 * * *$ \\
\hline & $(1.923)$ & $(1.971)$ & $(1.709)$ & $(1.873)$ & $(1.258)$ & $(1.243)$ & $(1.430)$ & $(1.453)$ \\
\hline \multirow[t]{2}{*}{ Turnout } & 0.116 & 0.112 & -0.088 & -0.092 & 0.312 & 0.314 & -0.014 & -0.015 \\
\hline & $(0.172)$ & $(0.172)$ & $(0.191)$ & $(0.190)$ & $(0.210)$ & $(0.211)$ & $(0.228)$ & $(0.228)$ \\
\hline \multirow[t]{2}{*}{ Union density } & -0.156 & -0.143 & $-0.662^{*}$ & $-0.669^{*}$ & -0.028 & -0.025 & -0.236 & -0.207 \\
\hline & $(0.160)$ & $(0.155)$ & $(0.348)$ & $(0.336)$ & $(0.174)$ & $(0.172)$ & $(0.452)$ & $(0.492)$ \\
\hline \multirow[t]{2}{*}{ Higher education } & 0.011 & 0.039 & -0.105 & -0.065 & 0.023 & 0.021 & -0.113 & -0.107 \\
\hline & $(0.087)$ & $(0.094)$ & $(0.128)$ & $(0.141)$ & $(0.139)$ & $(0.138)$ & $(0.154)$ & $(0.153)$ \\
\hline \multirow[t]{2}{*}{ District magnitude (\%) } & $3.193^{* *}$ & $3.037^{* *}$ & $2.501^{* * *}$ & $2.341 * * *$ & 2.119 & 2.101 & $1.774^{* * *}$ & $1.764^{* *}$ \\
\hline & $(1.387)$ & $(1.314)$ & $(0.703)$ & $(0.687)$ & $(1.690)$ & $(1.653)$ & $(0.623)$ & $(0.626)$ \\
\hline \multirow[t]{2}{*}{ Employment in agriculture } & 0.443 & 0.347 & 0.371 & 0.251 & 0.106 & 0.113 & -0.852 & -0.918 \\
\hline & $(0.263)$ & $(0.244)$ & $(0.849)$ & $(0.743)$ & $(0.297)$ & $(0.299)$ & $(0.693)$ & $(0.740)$ \\
\hline \multirow[t]{2}{*}{ Women in work } & 0.075 & 0.096 & -0.269 & -0.220 & -0.056 & -0.091 & -0.027 & 0.018 \\
\hline & $(0.213)$ & $(0.222)$ & $(0.189)$ & $(0.198)$ & $(0.305)$ & $(0.340)$ & $(0.302)$ & $(0.355)$ \\
\hline \multirow[t]{2}{*}{ Urban population } & -0.407 & -0.292 & -0.452 & -0.251 & -1.071 & -0.980 & -1.075 & -1.178 \\
\hline & $(0.316)$ & $(0.352)$ & $(0.419)$ & $(0.414)$ & $(1.303)$ & $(1.388)$ & $(1.248)$ & $(1.402)$ \\
\hline \multirow[t]{2}{*}{ Population (log) } & 0.091 & 1.331 & $36.301^{*}$ & $38.016^{*}$ & -32.993 & -28.514 & -10.697 & -14.727 \\
\hline & $(16.104)$ & $(16.198)$ & $(19.970)$ & $(19.812)$ & $(49.717)$ & $(48.114)$ & $(52.510)$ & $(52.238)$ \\
\hline \multirow[t]{2}{*}{ Population aged 65 and over } & 0.112 & 0.365 & 1.045 & 1.434 & $-1.987^{*}$ & $-1.988^{*}$ & -1.774 & -1.809 \\
\hline & $(0.970)$ & $(1.058)$ & $(0.938)$ & $(1.038)$ & $(1.115)$ & $(1.118)$ & $(1.456)$ & $(1.495)$ \\
\hline \multirow[t]{2}{*}{ Population aged 0 to 14} & 0.796 & 0.886 & 1.194 & 1.376 & 0.450 & 0.587 & 1.399 & 1.288 \\
\hline & $(0.853)$ & $(0.861)$ & $(0.825)$ & $(0.859)$ & $(1.126)$ & $(1.185)$ & $(1.267)$ & $(1.301)$ \\
\hline Country fixed effects & Yes & Yes & Yes & Yes & Yes & Yes & Yes & Yes \\
\hline Decade fixed-effects & Yes & Yes & Yes & Yes & Yes & Yes & Yes & Yes \\
\hline Country-year effects & No & Yes & No & Yes & No & Yes & No & Yes \\
\hline Observations & 180 & 180 & 141 & 141 & 170 & 170 & 136 & 136 \\
\hline R-squared & 0.204 & 0.209 & 0.323 & 0.341 & 0.270 & 0.271 & 0.333 & 0.334 \\
\hline Number of countries & 27 & 27 & 22 & 22 & 27 & 27 & 22 & 22 \\
\hline
\end{tabular}

Note: Dependent variable: social democratic party vote share. Models 1, 2, 3, and 4 estimate effects on the overall level of support for social democratic parties, Models 5, 6, 7, and 8 estimate changes in support between elections (first differences) Standard errors in parentheses. 
Table A6: Correlates of Social Democratic votes in the era of globalization, 2000-2017

\begin{tabular}{|c|c|c|c|c|c|c|c|c|}
\hline & \multicolumn{4}{|c|}{ Analysis of levels } & \multicolumn{4}{|c|}{ Analysis of differences } \\
\hline & (1) & $(2)$ & (3) & $(4)$ & $(5)$ & (6) & (7) & $(8)$ \\
\hline \multirow[t]{2}{*}{ Public Spending ( $\%$ of GDP) } & $0.818^{* *}$ & $0.792^{* *}$ & & & $0.646^{* *}$ & $0.644^{* *}$ & & \\
\hline & $(0.304)$ & $(0.293)$ & & & $(0.312)$ & $(0.313)$ & & \\
\hline \multirow[t]{2}{*}{ Welfare spending ( $\%$ GDP) } & & & $1.900^{* * *}$ & $1.873^{* * *}$ & & & $1.497^{* *}$ & $1.615^{* *}$ \\
\hline & & & $(0.574)$ & $(0.493)$ & & & $(0.690)$ & $(0.668)$ \\
\hline \multirow[t]{2}{*}{ Employment in industry (\%) } & 0.632 & 0.578 & $1.949^{*}$ & $1.785^{*}$ & 0.354 & 0.340 & 0.652 & 0.565 \\
\hline & $(0.761)$ & $(0.756)$ & $(1.001)$ & $(1.022)$ & $(0.515)$ & $(0.566)$ & $(0.725)$ & $(0.704)$ \\
\hline \multirow[t]{2}{*}{ Globalization Index } & $0.983^{* *}$ & $1.106^{* *}$ & $1.118^{*}$ & $1.493^{*}$ & 0.423 & 0.434 & 0.281 & 0.568 \\
\hline & $(0.366)$ & $(0.424)$ & $(0.623)$ & $(0.753)$ & $(0.487)$ & $(0.475)$ & $(0.716)$ & $(0.723)$ \\
\hline \multirow[t]{2}{*}{ Social Democrat left-right position } & 0.029 & 0.035 & 0.114 & 0.133 & -0.037 & -0.038 & -0.007 & -0.008 \\
\hline & $(0.061)$ & $(0.064)$ & $(0.097)$ & $(0.100)$ & $(0.046)$ & $(0.045)$ & $(0.080)$ & $(0.077)$ \\
\hline \multirow[t]{2}{*}{ Centre Right left-right position } & $-0.137^{*}$ & $-0.143^{* *}$ & -0.006 & -0.038 & $-0.155^{* * *}$ & $-0.155^{* * *}$ & -0.073 & -0.076 \\
\hline & $(0.067)$ & $(0.064)$ & $(0.066)$ & $(0.068)$ & $(0.048)$ & $(0.048)$ & $(0.107)$ & $(0.113)$ \\
\hline \multirow[t]{2}{*}{ SD party in gov't (single-party) } & 0.359 & 0.153 & -1.581 & -2.269 & -1.011 & -1.018 & -4.025 & -4.292 \\
\hline & $(3.413)$ & $(3.410)$ & $(4.283)$ & $(4.348)$ & $(2.040)$ & $(2.065)$ & $(2.907)$ & $(2.825)$ \\
\hline \multirow[t]{2}{*}{ SD party in gov't (coalition-PM) } & -1.725 & -1.776 & 0.334 & -0.103 & $-3.515^{*}$ & $-3.511^{*}$ & -2.334 & -2.597 \\
\hline & $(1.557)$ & $(1.548)$ & $(1.482)$ & $(1.509)$ & $(1.829)$ & $(1.838)$ & $(2.037)$ & $(2.042)$ \\
\hline \multirow[t]{2}{*}{ SD party in gov't (coalition-junior) } & $-4.571^{* *}$ & $-4.757^{* *}$ & -3.409 & $-4.184^{*}$ & $-4.281^{*}$ & $-4.282^{*}$ & $-4.740^{*}$ & $-4.725^{*}$ \\
\hline & $(1.767)$ & $(1.797)$ & $(2.103)$ & $(2.328)$ & $(2.151)$ & $(2.162)$ & $(2.690)$ & $(2.671)$ \\
\hline \multirow[t]{2}{*}{ Turnout } & -0.007 & 0.011 & -0.346 & -0.287 & 0.094 & 0.096 & -0.085 & -0.034 \\
\hline & $(0.245)$ & $(0.234)$ & $(0.265)$ & $(0.239)$ & $(0.246)$ & $(0.243)$ & $(0.348)$ & $(0.331)$ \\
\hline \multirow[t]{2}{*}{ Union density } & $-1.403^{* * *}$ & $-1.406^{* * *}$ & $-1.662^{* * *}$ & $-1.682^{* * *}$ & $-0.603^{*}$ & $-0.607^{*}$ & -0.305 & -0.286 \\
\hline & $(0.324)$ & $(0.318)$ & $(0.471)$ & $(0.439)$ & $(0.326)$ & $(0.338)$ & $(0.658)$ & $(0.664)$ \\
\hline \multirow[t]{2}{*}{ Higher education } & -0.132 & -0.129 & -0.192 & -0.198 & -0.153 & -0.153 & -0.154 & -0.117 \\
\hline & $(0.154)$ & $(0.156)$ & $(0.175)$ & $(0.177)$ & $(0.153)$ & $(0.156)$ & $(0.188)$ & $(0.187)$ \\
\hline \multirow[t]{2}{*}{ District magnitude (\%) } & $6.667^{* * *}$ & $6.795^{* * *}$ & $5.831^{* * *}$ & $6.178^{* * *}$ & $8.456^{* * *}$ & $8.463^{* * *}$ & $7.998^{* * *}$ & $8.005^{* * *}$ \\
\hline & $(0.696)$ & $(0.658)$ & $(0.858)$ & $(1.010)$ & $(0.856)$ & $(0.869)$ & $(2.681)$ & $(2.794)$ \\
\hline \multirow[t]{2}{*}{ Employment in agriculture } & 0.153 & 0.075 & -0.282 & -0.529 & 0.518 & 0.516 & -1.062 & -1.083 \\
\hline & $(0.519)$ & $(0.555)$ & $(1.308)$ & $(1.339)$ & $(0.572)$ & $(0.575)$ & $(1.381)$ & $(1.378)$ \\
\hline \multirow[t]{2}{*}{ Women in work } & 0.262 & -0.202 & -0.571 & -0.432 & -0.168 & -0.166 & -0.025 & 0.154 \\
\hline & $(0.450)$ & $(0.494)$ & $(0.473)$ & $(0.484)$ & $(0.607)$ & $(0.611)$ & $(0.834)$ & $(0.883)$ \\
\hline \multirow[t]{2}{*}{ Urban population } & 0.452 & 0.660 & -0.069 & 0.333 & -2.729 & -2.727 & $-5.336^{* * *}$ & $-5.408^{* * *}$ \\
\hline & $(0.861)$ & $(0.888)$ & $(1.135)$ & $(1.140)$ & $(2.544)$ & $(2.555)$ & $(1.876)$ & $(1.799)$ \\
\hline \multirow[t]{2}{*}{ Population (log) } & -15.089 & -13.923 & 69.958 & $76.205^{*}$ & 12.364 & 12.418 & 33.798 & 33.826 \\
\hline & $(20.793)$ & $(20.159)$ & $(41.905)$ & $(43.486)$ & $(65.421)$ & $(65.911)$ & $(75.560)$ & $(81.849)$ \\
\hline \multirow[t]{2}{*}{ Population aged 65 and over } & -1.185 & -0.683 & 0.048 & 1.235 & -0.970 & -0.981 & -0.229 & -0.498 \\
\hline & $(1.364)$ & $(1.956)$ & $(1.417)$ & $(1.895)$ & $(1.871)$ & $(1.854)$ & $(2.403)$ & $(2.282)$ \\
\hline \multirow[t]{2}{*}{ Population aged 0 to 14} & $6.257^{* * *}$ & $6.341^{* * *}$ & $6.919^{* * *}$ & $6.809^{* * *}$ & 2.697 & 2.669 & 3.208 & 2.828 \\
\hline & $(1.321)$ & $(1.364)$ & $(1.683)$ & $(1.582)$ & $(2.041)$ & $(2.030)$ & $(2.306)$ & $(2.093)$ \\
\hline Country fixed effects & Yes & Yes & Yes & Yes & Yes & Yes & Yes & Yes \\
\hline Decade fixed-effects & Yes & Yes & Yes & Yes & Yes & Yes & Yes & Yes \\
\hline Country-year effects & No & Yes & No & Yes & No & Yes & No & Yes \\
\hline Observations & 107 & 107 & 84 & 84 & 107 & 107 & 84 & 84 \\
\hline R-squared & 0.502 & 0.505 & 0.534 & 0.548 & 0.452 & 0.452 & 0.403 & 0.415 \\
\hline Number of countries & 27 & 27 & 22 & 22 & 27 & 27 & 22 & 22 \\
\hline
\end{tabular}

Note: Dependent variable: social democratic party vote share. Models 1, 2, 3, and 4 estimate effects on the overall level of support for social democratic parties. Models 5, 6, 7, and 8 estimate changes in support between elections (first differences) Standard errors in parentheses. 
Table A7: SD Economic and Social Left Right position over the period 1945 to 2017

\begin{tabular}{lccc}
\hline \hline & Aggregate Sample & Non East Europe & East Europe \\
& $(1)$ & $(2)$ & $(3)$ \\
\hline SD economic left-right position & $0.170^{* *}$ & 0.0747 & $0.554^{* *}$ \\
SD social left-right position & $(0.0712)$ & $(0.0471)$ & $(0.220)$ \\
& $0.156^{* *}$ & 0.0829 & $0.549^{* * *}$ \\
Centre Right economic left-right position & $(0.0702)$ & $(0.0562)$ & $(0.161)$ \\
& 0.0233 & 0.0494 & -0.122 \\
Centre Right social left-right position & $(0.0448)$ & $(0.0451)$ & $(0.0993)$ \\
& -0.0312 & $-0.0726^{*}$ & 0.0960 \\
\hline Control Variables & $(0.0482)$ & $(0.0376)$ & $(0.118)$ \\
Country fixed effects & Yes & Yes & Yes \\
Decade fixed effects & Yes & Yes & Yes \\
Country-year effects & Yes & Yes & Yes \\
\hline Observations & Yes & Yes & Yes \\
R-squared & 386 & 298 & 88 \\
Number of countries & 0.171 & 0.249 & 0.457 \\
\hline \hline
\end{tabular}

Note: Dependent variable: social democratic party vote share. All models estimate effects on the overall level of support for social democratic parties. Standard errors in parentheses. 
Table A8: Robustness tests: social democratic party vote share vs. social democratic, including the Italian Communist party, vote share vs. total left vote share and vs. centre right vote share as dependent variables, 1945-2017

\begin{tabular}{|c|c|c|c|c|}
\hline & (1) & $(2)$ & (3) & (4) \\
\hline & Soc. Dem. vote share & SD with Communist Party & Total Left vote share & C. Right vote share \\
\hline \multirow[t]{2}{*}{ Public Spending (\% GDP) } & $0.192^{* * *}$ & $0.207^{* * *}$ & 0.0843 & 0.143 \\
\hline & $(0.0594)$ & $(0.0602)$ & $(0.0725)$ & $(0.0888)$ \\
\hline \multirow[t]{2}{*}{ District Magnitude (log) } & 2.612 & $3.444^{* * *}$ & $2.714^{* *}$ & 0.787 \\
\hline & $(1.652)$ & $(1.250)$ & $(1.072)$ & $(1.110)$ \\
\hline \multirow[t]{2}{*}{ Turnout } & -0.172 & -0.162 & -0.131 & 0.0868 \\
\hline & $(0.107)$ & $(0.104)$ & $(0.122)$ & $(0.144)$ \\
\hline \multirow[t]{2}{*}{ GDP per capita (Madison) } & $6.958^{* *}$ & $7.822^{* *}$ & 6.560 & 0.752 \\
\hline & $(2.928)$ & $(2.883)$ & $(4.066)$ & $(5.049)$ \\
\hline \multirow[t]{2}{*}{ GDP growth (Madison) } & -0.0666 & -0.0453 & -0.152 & 0.187 \\
\hline & $(0.159)$ & $(0.157)$ & $(0.177)$ & $(0.160)$ \\
\hline Controls & Yes & Yes & Yes & Yes \\
\hline Country Fes & Yes & Yes & Yes & Yes \\
\hline Decade Fes & Yes & Yes & Yes & Yes \\
\hline Country-year time trends & Yes & Yes & Yes & Yes \\
\hline Observations & 409 & 409 & 409 & 409 \\
\hline R-squared & 0.159 & 0.188 & 0.088 & 0.167 \\
\hline Number of countries & 31 & 31 & 31 & 31 \\
\hline
\end{tabular}

Note: Column 1 exhibits estimates for Soc. Dem as in Table 3; Column 2, includes the Italian Communist Party; Column 3 focuses on total left and Column 4 total right. All models are conditional on country Fes, Decade Fes and, progressively,

Country Year Time Trends. Standard errors in parentheses. Controls include regime types, european membership and parties left and right social and economic position. 
Table A9: Robustness tests: social democratic party vote share vs. total left vote share and vs. centre right vote share as dependent variables, 1975-2017

\begin{tabular}{|c|c|c|c|c|}
\hline & (1) & $(2)$ & $(3)$ & (4) \\
\hline & Soc. Dem. vote share & SD with Communist Party & Total Left vote share & C. Right vote share \\
\hline \multirow[t]{2}{*}{ Public Spending (\% GDP) } & $0.753^{* * *}$ & $0.737^{* * *}$ & 0.140 & 0.202 \\
\hline & $(0.260)$ & $(0.250)$ & $(0.352)$ & $(0.271)$ \\
\hline \multirow[t]{2}{*}{ District Magnitude (log) } & $0.655^{* *}$ & $0.546^{*}$ & -0.114 & 0.385 \\
\hline & $(0.313)$ & $(0.293)$ & $(0.301)$ & $(0.336)$ \\
\hline \multirow[t]{2}{*}{ Turnout } & 0.164 & 0.373 & 0.198 & 0.104 \\
\hline & $(0.400)$ & $(0.346)$ & $(0.410)$ & $(0.476)$ \\
\hline \multirow[t]{2}{*}{ GDP per capita (Madison) } & 0.156 & 0.126 & 0.115 & -0.0295 \\
\hline & $(0.118)$ & $(0.114)$ & $(0.152)$ & $(0.155)$ \\
\hline \multirow[t]{2}{*}{ GDP growth (Madison) } & $-0.380 * *$ & $-0.391^{* *}$ & -0.212 & -0.285 \\
\hline & $(0.177)$ & $(0.180)$ & $(0.172)$ & $(0.288)$ \\
\hline Controls & Yes & Yes & Yes & Yes \\
\hline Country Fes & Yes & Yes & Yes & Yes \\
\hline Decade Fes & Yes & Yes & Yes & Yes \\
\hline Country-year time trends & Yes & Yes & Yes & Yes \\
\hline Observations & 209 & 209 & 209 & 209 \\
\hline R-squared & 0.317 & 0.337 & 0.160 & 0.294 \\
\hline Number of countries & 22 & 22 & 22 & 22 \\
\hline
\end{tabular}

Note: Column 1 exhibits estimates for Soc. Dem as in Table 3; Column 2, includes the Italian Communist Party; Column 3

focuses on total left and Column 4 total right. All models are conditional on country Fes, Decade Fes and, progressively,

Country Year Time Trends. Standard errors in parentheses. Controls include regime types, european membership and parties left and right social and economic position. 
Table A10: Heterogeneity Analysis, 1945-2017

\begin{tabular}{|c|c|c|c|c|}
\hline & \multicolumn{2}{|c|}{ Western Europe } & \multicolumn{2}{|c|}{ Eastern Europe } \\
\hline & (1) & $(2)$ & $(3)$ & $(4)$ \\
\hline \multirow[t]{2}{*}{ Public spending (\% ofGDP) } & $0.0954^{*}$ & $0.131^{* *}$ & $1.167^{* * *}$ & $1.343^{* *}$ \\
\hline & $(0.0505)$ & $(0.0548)$ & $(0.370)$ & $(0.457)$ \\
\hline \multirow[t]{2}{*}{ District magnitude (log) } & -0.706 & -0.534 & 3.809 & 3.134 \\
\hline & $(0.737)$ & $(0.744)$ & $(4.305)$ & $(4.198)$ \\
\hline \multirow[t]{2}{*}{ District mag.*SD left-right position } & -0.00435 & -0.00235 & 0.0338 & 0.029 \\
\hline & $(0.0075)$ & $(0.0075)$ & $(0.035)$ & $(0.037)$ \\
\hline \multirow[t]{2}{*}{ Social democratic party in government } & 0.572 & 0.323 & -2.536 & -2.277 \\
\hline & $(0.900)$ & $(0.805)$ & $(1.609)$ & $(1.682)$ \\
\hline \multirow[t]{2}{*}{ Turnout } & -0.0093 & -0.0084 & -0.189 & -0.113 \\
\hline & $(0.117)$ & $(0.105)$ & $(0.169)$ & $(0.202)$ \\
\hline \multirow[t]{2}{*}{ GDP per capita (Madison) } & 2.878 & 4.506 & 8.073 & 3.267 \\
\hline & $(2.984)$ & $(3.729)$ & $(4.855)$ & $(6.089)$ \\
\hline \multirow[t]{2}{*}{ GDP growth (Madison) } & -0.130 & -0.0744 & -0.321 & -0.379 \\
\hline & $(0.121)$ & $(0.142)$ & $(0.358)$ & $(0.349)$ \\
\hline \multirow[t]{2}{*}{ Eu member } & -1.079 & -0.405 & -5.546 & -7.264 \\
\hline & $(2.487)$ & $(2.500)$ & $(4.046)$ & $(4.923)$ \\
\hline \multirow[t]{2}{*}{ Presidential system } & $11.51^{* * *}$ & $10.96^{* * *}$ & 4.657 & 5.523 \\
\hline & $(1.656)$ & $(1.631)$ & $(7.391)$ & $(8.090)$ \\
\hline Country fixed effects & Yes & Yes & Yes & Yes \\
\hline Decade fixed effects & Yes & Yes & Yes & Yes \\
\hline Country-year effects & No & Yes & No & Yes \\
\hline Observations & 294 & 294 & 87 & 87 \\
\hline R-squared & 0.135 & 0.150 & 0.242 & 0.248 \\
\hline Number of countries & 18 & 18 & 13 & 13 \\
\hline
\end{tabular}

Note: Dependent variable: social democratic party vote share. Columns 1 and 2 estimate effects on the overall level of support for social democratic parties in Western Europe. Western Europe includes Southern European and Scandinavian countries. Columns 3 and 4 estimate the overall level of support for SD parties in Eastern Europe. Standard errors in parentheses. 
Table A11: Heterogeneity Analysis within Western Europe, 1945-2017

\begin{tabular}{lcccc}
\hline \hline & Western Europe & \multicolumn{2}{c}{ Southern Europe } & Scandinavia \\
& $(1)$ & $(2)$ & $(3)$ & $(4)$ \\
\hline Public spending (\% of GDP) & 0.119 & $-0.612^{* *}$ & -0.328 & 0.0284 \\
& $(0.112)$ & $(0.149)$ & $(0.293)$ & $(0.114)$ \\
District magnitude (log) & -1.776 & -0.239 & 1.826 & 2.587 \\
& $(1.538)$ & $(0.563)$ & $(1.041)$ & $(3.912)$ \\
District mag.*SD left-right position & 0.0125 & 0.0614 & 0.0450 & -0.000531 \\
& $(0.0138)$ & $(0.0310)$ & $(0.0336)$ & $(0.00912)$ \\
Social democratic party in government & -1.233 & 0.0705 & -0.0491 & 0.423 \\
Turnout & $(0.841)$ & $(1.523)$ & $(1.690)$ & $(0.424)$ \\
& 0.0753 & $0.549^{*}$ & 0.585 & -0.241 \\
GDP per capita (Madison) & $(0.154)$ & $(0.252)$ & $(0.299)$ & $(0.149)$ \\
R-squared & $12.03^{* *}$ & -9.341 & -5.258 & 0.246 \\
Number of countries & $(4.172)$ & $(12.41)$ & $(16.83)$ & $(3.709)$ \\
\hline GDP growth (Madison) & 0.0536 & $-1.125^{* *}$ & $-0.842^{*}$ & 0.221 \\
Country fixed effects & Yes & Yes & Yes & Yes \\
\hline \hline Observations & $(0.141)$ & $(0.257)$ & $(0.356)$ & $(0.147)$ \\
& $-4.317^{* *}$ & $11.71^{*}$ & $15.38^{* *}$ & -1.589 \\
\hline & $(1.699)$ & $(4.672)$ & $(4.439)$ & $(3.641)$ \\
\hline
\end{tabular}

Note: Columns 1 exhibits estimates on the overall level of support for social democratic parties in Western Europe. Column 2 and 3 focus on Southern Europe. Column 2 studies the effect on SD parties, Column 3 includes the Italian Communist Party. Column 4 focuses on Scandinavian countries. All estimates are conditional on country fixed effects, decade fixed effects and, progressively, country year specific time trends. Standard errors in parentheses. 
Table A12: Randomization, 1950-2017

\begin{tabular}{lcc}
\hline \hline & \multicolumn{2}{c}{ Post-1950 } \\
& Analysis of levels & Analysis of differences \\
& $(1)$ & $(2)$ \\
\hline Public spending (\% of GDP) & $0.197^{* *}$ & $0.148^{* *}$ \\
Social Democrat left-right position & $(0.079)$ & $(0.066)$ \\
& 0.158 & $0.134^{* *}$ \\
Centre Right left-right position & $(0.097)$ & $(0.059)$ \\
& -0.012 & -0.034 \\
District magnitude (log) & $(0.040)$ & $(0.028)$ \\
& 0.139 & 0.970 \\
District mag.*SD left-right position & $(1.537)$ & $(1.455)$ \\
& -0.046 & $-0.056^{* *}$ \\
Social democratic party in government & $(0.035)$ & $(0.025)$ \\
& 1.250 & $-6.392^{* * *}$ \\
Turnout (\%) & $(1.175)$ & $(1.308)$ \\
& -0.123 & $0.287^{* *}$ \\
Controls & $(0.107)$ & $(0.122)$ \\
Country fixed-effects & Yes & Yes \\
Decade fixed-effects & Yes & Yes \\
Country-year time trends & Yes & Yes \\
\hline Observations & Yes & Yes \\
R-squared & 381 & 353 \\
Number of countries & 0.176 & 0.170 \\
\hline \hline
\end{tabular}

Note: Dependent variable: social democratic party vote share. Column 1 estimates effects on the overall level of support for social democratic parties, whereas Column 2 estimates changes in support between elections (first differences). The estimates replicate Table 3, but with a different time period, from 1950 onwards. Standard errors in parentheses. Results not shown for the constant and the control variables: GDP per capita (log), GDP growth, EU member, Eurozone member, presidential system. 
Table A13: Randomization, 1970-2017 and 1980-2017

\begin{tabular}{|c|c|c|c|c|c|c|c|c|}
\hline & \multicolumn{4}{|c|}{ Post-1970 } & \multicolumn{4}{|c|}{ Post-1980 } \\
\hline & \multicolumn{2}{|c|}{$\begin{array}{l}\text { Analysis of levels } \\
\begin{array}{ll}(1) & (2)\end{array}\end{array}$} & \multicolumn{2}{|c|}{ Analysis of differences } & \multicolumn{2}{|c|}{ Analysis of levels } & \multicolumn{2}{|c|}{ Analysis of differences } \\
\hline Welfare spending ( $\%$ of GDP) & & $\begin{array}{c}0.613^{* *} \\
(0.238)\end{array}$ & & $\begin{array}{c}0.794^{* *} \\
(0.362)\end{array}$ & & $\begin{array}{c}0.675^{* *} \\
(0.241)\end{array}$ & & $\begin{array}{c}0.794^{* *} \\
(0.362)\end{array}$ \\
\hline Globalization index & $\begin{array}{c}0.030 \\
(0.327)\end{array}$ & $\begin{array}{c}0.211 \\
(0.437)\end{array}$ & $\begin{array}{c}0.261 \\
(0.488)\end{array}$ & $\begin{array}{c}0.455 \\
(0.426)\end{array}$ & $\begin{array}{c}0.093 \\
(0.362)\end{array}$ & $\begin{array}{c}0.263 \\
(0.447)\end{array}$ & $\begin{array}{l}0.297 \\
(0.496)\end{array}$ & $\begin{array}{c}0.455 \\
(0.426)\end{array}$ \\
\hline Social Democrat left-right position & $\begin{array}{c}0.078 \\
(0.048)\end{array}$ & $\begin{array}{c}0.048 \\
(0.035)\end{array}$ & $\begin{array}{l}0.008 \\
(0.036)\end{array}$ & $\begin{array}{c}0.018 \\
(0.030)\end{array}$ & $\begin{array}{c}0.105^{* *} \\
(0.050)\end{array}$ & $\begin{array}{c}0.049 \\
(0.040)\end{array}$ & $\begin{array}{c}0.019 \\
(0.038)\end{array}$ & $\begin{array}{l}0.018 \\
(0.030)\end{array}$ \\
\hline Centre Right left-right position & $\begin{array}{c}0.002 \\
(0.048)\end{array}$ & $\begin{array}{c}0.053 \\
(0.055)\end{array}$ & $\begin{array}{l}-0.052 \\
(0.042)\end{array}$ & $\begin{array}{l}-0.023 \\
(0.043)\end{array}$ & $\begin{array}{c}0.002 \\
(0.055)\end{array}$ & $\begin{array}{c}0.050 \\
(0.056)\end{array}$ & $\begin{array}{l}-0.054 \\
(0.043)\end{array}$ & $\begin{array}{l}-0.023 \\
(0.043)\end{array}$ \\
\hline Union Density & $\begin{array}{l}-0.192 \\
(0.116)\end{array}$ & $\begin{array}{c}-0.463^{* *} \\
(0.191)\end{array}$ & $\begin{array}{l}-0.120 \\
(0.144)\end{array}$ & $\begin{array}{l}-0.436 \\
(0.292)\end{array}$ & $\begin{array}{l}-0.183 \\
(0.140)\end{array}$ & $\begin{array}{c}-0.517^{* *} \\
(0.214)\end{array}$ & $\begin{array}{l}-0.125 \\
(0.161)\end{array}$ & $\begin{array}{l}-0.436 \\
(0.292)\end{array}$ \\
\hline Controls & Yes & Yes & Yes & Yes & Yes & Yes & Yes & Yes \\
\hline Country fixed-effects & Yes & Yes & Yes & Yes & Yes & Yes & Yes & Yes \\
\hline Decade fixed-effects & Yes & Yes & Yes & Yes & Yes & Yes & Yes & Yes \\
\hline Country-year time trends & Yes & Yes & Yes & Yes & Yes & Yes & Yes & Yes \\
\hline Observations & 244 & 193 & 244 & 193 & 227 & 171 & 227 & 171 \\
\hline R-squared & 0.223 & 0.308 & 0.240 & 0.335 & 0.234 & 0.343 & 0.239 & 0.344 \\
\hline Number of countries & 27 & 22 & 27 & 22 & 27 & 22 & 27 & 22 \\
\hline
\end{tabular}

Note: Dependent variable: social democratic party vote share. Columns 1,2,5, and 6 estimate effects on the overall level of support for social democratic parties, whereas Columns 3, 4, 7, and 8 estimate changes in support between elections (first differences). Estimates replicate Table 4, but with a different time period. Precisely, Columns 1 to 4 perform the analysis from 1970 onwards, whereas Columns 5 to 8 do so from 1980 onwards. Standard errors in parentheses. Results not shown for the constant, and the control variables: employment in agriculture, women in work, urban population, life expectancy, population $(\log )$, population aged 65 and over, population aged 0 to 14, percent in higher education. 
Table A14: Randomization, 1985-2017, 1995-2017, and 2005-2017

\begin{tabular}{|c|c|c|c|c|c|c|}
\hline & \multicolumn{2}{|c|}{ Post-1985 } & \multicolumn{2}{|c|}{$\begin{array}{c}\text { Post-1995 } \\
\text { Analysis of levels }\end{array}$} & \multicolumn{2}{|c|}{ Post-2005 } \\
\hline & $(1)$ & $(2)$ & & & $(5)$ & $(6)$ \\
\hline Public spending ( $\%$ of GDP) & $\begin{array}{c}0.223 \\
(0.151)\end{array}$ & & $\begin{array}{c}0.505^{* *} \\
(0.209)\end{array}$ & & $\begin{array}{l}0.746^{*} \\
(0.396)\end{array}$ & \\
\hline Public spending on social welfare ( $\%$ of GDP) & & $\begin{array}{c}0.905^{* * *} \\
(0.239)\end{array}$ & & $\begin{array}{l}1.032 * * \\
(0.381)\end{array}$ & & $\begin{array}{c}0.843 \\
(0.786)\end{array}$ \\
\hline Employment in industry (\%) & $\begin{array}{l}0.627^{*} \\
(0.354)\end{array}$ & $\begin{array}{l}1.007^{* *} \\
(0.447)\end{array}$ & $\begin{array}{c}0.547 \\
(0.548)\end{array}$ & $\begin{array}{c}1.033 \\
(0.630)\end{array}$ & $\begin{array}{c}0.428 \\
(1.549)\end{array}$ & $\begin{array}{c}1.507 \\
(1.862)\end{array}$ \\
\hline Globalization index & $\begin{array}{c}0.248 \\
(0.410)\end{array}$ & $\begin{array}{c}0.475 \\
(0.421)\end{array}$ & $\begin{array}{c}0.930 * * * \\
(0.212)\end{array}$ & $\begin{array}{l}0.984^{* *} \\
(0.473)\end{array}$ & $\begin{array}{l}-0.608 \\
(0.994)\end{array}$ & $\begin{array}{l}-2.814 \\
(2.442)\end{array}$ \\
\hline Social Democrat left-right position & $\begin{array}{c}0.112 \\
(0.068)\end{array}$ & $\begin{array}{c}0.033 \\
(0.050)\end{array}$ & $\begin{array}{l}0.116^{*} \\
(0.062)\end{array}$ & $\begin{array}{l}0.128^{*} \\
(0.062)\end{array}$ & $\begin{array}{c}0.052 \\
(0.066)\end{array}$ & $\begin{array}{c}0.007 \\
(0.104)\end{array}$ \\
\hline Centre Right left-right position & $\begin{array}{c}0.007 \\
(0.057)\end{array}$ & $\begin{array}{c}0.075 \\
(0.054)\end{array}$ & $\begin{array}{c}-0.123^{* *} \\
(0.051)\end{array}$ & $\begin{array}{c}0.007 \\
(0.068)\end{array}$ & $\begin{array}{c}-0.186^{* * *} \\
(0.048)\end{array}$ & $\begin{array}{c}0.021 \\
(0.132)\end{array}$ \\
\hline Social democratic party in government & $\begin{array}{l}-2.833^{*} \\
(1.424)\end{array}$ & $\begin{array}{l}-3.292^{*} \\
(1.615)\end{array}$ & $\begin{array}{c}-2.289^{*} \\
(1.322)\end{array}$ & $\begin{array}{l}-2.743 \\
(1.752)\end{array}$ & $\begin{array}{l}-2.714 \\
(2.694)\end{array}$ & $\begin{array}{c}0.260 \\
(2.781)\end{array}$ \\
\hline Turnout $(\%)$ & $\begin{array}{c}0.083 \\
(0.166)\end{array}$ & $\begin{array}{l}-0.073 \\
(0.167)\end{array}$ & $\begin{array}{l}-0.004 \\
(0.179)\end{array}$ & $\begin{array}{l}-0.147 \\
(0.219)\end{array}$ & $\begin{array}{c}0.171 \\
(0.206)\end{array}$ & $\begin{array}{c}0.650 \\
(0.532)\end{array}$ \\
\hline $\begin{array}{l}\text { Observations } \\
\text { R-squared } \\
\text { Number of countries }\end{array}$ & $\begin{array}{c}201 \\
0.171 \\
27\end{array}$ & $\begin{array}{c}162 \\
0.340 \\
22 \\
\end{array}$ & $\begin{array}{c}141 \\
0.496 \\
27 \\
\end{array}$ & $\begin{array}{c}111 \\
0.471 \\
22 \\
\end{array}$ & $\begin{array}{c}73 \\
0.474 \\
27 \\
\end{array}$ & $\begin{array}{c}58 \\
0.504 \\
22 \\
\end{array}$ \\
\hline Number of countries & $(7)$ & $(8)$ & $\begin{array}{l}\text { Analysis } \\
(9)\end{array}$ & $\begin{array}{l}\text { differences } \\
(10)\end{array}$ & $(11)$ & $(12)$ \\
\hline Public spending ( $\%$ of GDP) & $\begin{array}{l}0.297^{*} \\
(0.156)\end{array}$ & & $\begin{array}{c}0.661^{* *} \\
(0.250)\end{array}$ & & $\begin{array}{c}0.484 \\
(0.439)\end{array}$ & \\
\hline Public spending on social welfare ( $\%$ of GDP) & & $\begin{array}{c}0.873 * * \\
(0.399)\end{array}$ & & $\begin{array}{c}1.756^{* * *} \\
(0.528)\end{array}$ & & $\begin{array}{l}-0.269 \\
(1.036)\end{array}$ \\
\hline Employment in industry (\%) & $\begin{array}{l}-0.104 \\
(0.363)\end{array}$ & $\begin{array}{c}0.666 \\
(0.467)\end{array}$ & $\begin{array}{c}0.289 \\
(0.452)\end{array}$ & $\begin{array}{l}1.084^{*} \\
(0.536)\end{array}$ & $\begin{array}{l}-0.992 \\
(0.870)\end{array}$ & $\begin{array}{l}-0.909 \\
(1.354)\end{array}$ \\
\hline Globalization index & $\begin{array}{c}0.073 \\
(0.530)\end{array}$ & $\begin{array}{c}0.342 \\
(0.488)\end{array}$ & $\begin{array}{l}-0.270 \\
(0.748)\end{array}$ & $\begin{array}{c}0.460 \\
(0.597)\end{array}$ & $\begin{array}{l}-0.095 \\
(1.198)\end{array}$ & $\begin{array}{l}-0.027 \\
(1.373)\end{array}$ \\
\hline Social Democrat left-right position & $\begin{array}{c}0.006 \\
(0.047)\end{array}$ & $\begin{array}{c}0.002 \\
(0.036)\end{array}$ & $\begin{array}{l}0.006 \\
(0.066)\end{array}$ & $\begin{array}{l}-0.005 \\
(0.055)\end{array}$ & $\begin{array}{l}-0.086 \\
(0.079)\end{array}$ & $\begin{array}{c}0.051 \\
(0.144)\end{array}$ \\
\hline Centre Right left-right position & $\begin{array}{l}-0.058 \\
(0.046)\end{array}$ & $\begin{array}{l}-0.010 \\
(0.041)\end{array}$ & $\begin{array}{c}-0.110^{*} \\
(0.054)\end{array}$ & $\begin{array}{c}-0.016 \\
(0.079)\end{array}$ & $\begin{array}{c}-0.155^{*} \\
(0.086)\end{array}$ & $\begin{array}{l}-0.065 \\
(0.170)\end{array}$ \\
\hline Social democratic party in government & $\begin{array}{c}-4.432 * * * \\
(1.590)\end{array}$ & $\begin{array}{c}-3.420^{*} \\
(1.807)\end{array}$ & $\begin{array}{c}-3.559^{* *} \\
(1.404)\end{array}$ & $\begin{array}{c}-4.119^{*} \\
(2.214)\end{array}$ & $\begin{array}{c}-9.589 * * * \\
(2.559)\end{array}$ & $\begin{array}{c}-8.585 * * * \\
(2.724)\end{array}$ \\
\hline Turnout (\%) & $\begin{array}{l}0.349^{*} \\
(0.189)\end{array}$ & $\begin{array}{c}0.164 \\
(0.221)\end{array}$ & $\begin{array}{c}0.295 \\
(0.221)\end{array}$ & $\begin{array}{c}0.065 \\
(0.278)\end{array}$ & $\begin{array}{c}0.344 \\
(0.230)\end{array}$ & $\begin{array}{c}0.067 \\
(0.375)\end{array}$ \\
\hline Observations & 191 & 157 & 139 & 107 & 73 & 58 \\
\hline R-squared & 0.207 & 0.206 & 0.258 & 0.337 & 0.573 & 0.560 \\
\hline Number of countries & 27 & 22 & 27 & 22 & 27 & 22 \\
\hline Controls & Yes & Yes & Yes & Yes & Yes & Yes \\
\hline Country fixed-effects & Yes & Yes & Yes & Yes & Yes & Yes \\
\hline Decade fixed-effects & Yes & Yes & Yes & Yes & Yes & Yes \\
\hline Country-year time trends & Yes & Yes & Yes & Yes & Yes & Yes \\
\hline
\end{tabular}

Note: Dependent variable: social democratic party vote share. Models 1 to 6 estimate effects on the overall level of support for social democratic parties, whereas models 7 to 12 estimate changes in support between elections (first differences). The estimates replicate Table 5, but with a different time period. Precisely, Columns 1, 2, 7, and 8 perform the analysis for a period just before the end of the Cold-War, whereas Columns 3, 4, 9, and 10 for a period just after the end of it. Columns 5, 6, 11, and 12 perform the analysis for a period just after the Great Recession. Standard errors in parentheses. Results not shown for the constant and the control variables: employment in agriculture, women in work, urban population, population $(\log )$, population aged 65 and over, population aged 0 to 14 , union density, percent in higher education. 
Table A15: Individual-level correlates of voting or a social democratic party

\begin{tabular}{|c|c|c|c|c|c|c|c|c|}
\hline & $(1)$ & $(2)$ & (3) & (4) & $(5)$ & $(6)$ & $(7)$ & $(8)$ \\
\hline ESS Waves & $1-2002$ & $2-2004$ & $3-2006$ & $4-2008$ & $5-2010$ & $6-2012$ & $7-2014$ & $8-2016$ \\
\hline Worker in industry & $\begin{array}{c}0.0311^{* *} \\
(0.0107)\end{array}$ & $\begin{array}{c}0.0392^{* *} \\
(0.0132)\end{array}$ & $\begin{array}{c}0.0386^{* *} \\
(0.0137)\end{array}$ & $\begin{array}{c}0.0303^{* *} \\
(0.0129)\end{array}$ & $\begin{array}{c}0.0122 \\
(0.0122)\end{array}$ & $\begin{array}{c}0.0204 \\
(0.0150)\end{array}$ & $\begin{array}{l}0.0209^{*} \\
(0.0117)\end{array}$ & $\begin{array}{c}0.0189^{*} \\
(0.00885)\end{array}$ \\
\hline Public sector employee & $\begin{array}{c}0.0784^{* * *} \\
(0.0158)\end{array}$ & $\begin{array}{c}0.0862^{* * *} \\
(0.0187)\end{array}$ & $\begin{array}{c}0.0646^{* * *} \\
(0.0146)\end{array}$ & $\begin{array}{c}0.0805^{* * *} \\
(0.0130)\end{array}$ & $\begin{array}{c}0.0790 * * * \\
(0.0115)\end{array}$ & $\begin{array}{c}0.0632^{* * *} \\
(0.0121)\end{array}$ & $\begin{array}{c}0.0664^{* * *} \\
(0.00976)\end{array}$ & $\begin{array}{c}0.0583^{* * *} \\
(0.00992)\end{array}$ \\
\hline Socio- cultural professional & $\begin{array}{l}0.0241^{*} \\
(0.0126)\end{array}$ & $\begin{array}{c}0.0208 \\
(0.0142)\end{array}$ & $\begin{array}{c}0.0352 \\
(0.0200)\end{array}$ & $\begin{array}{l}0.0291^{*} \\
(0.0145)\end{array}$ & $\begin{array}{c}0.0131 \\
(0.0135)\end{array}$ & $\begin{array}{l}0.0402^{*} \\
(0.0188)\end{array}$ & $\begin{array}{c}0.0261 * * \\
(0.0121)\end{array}$ & $\begin{array}{l}0.0245^{*} \\
(0.0115)\end{array}$ \\
\hline Male & $\begin{array}{c}0.0108 \\
(0.00640)\end{array}$ & $\begin{array}{c}0.00461 \\
(0.00664)\end{array}$ & $\begin{array}{c}0.00101 \\
(0.00732)\end{array}$ & $\begin{array}{l}-0.00188 \\
(0.00456)\end{array}$ & $\begin{array}{c}0.00287 \\
(0.00671)\end{array}$ & $\begin{array}{c}0.00502 \\
(0.00586)\end{array}$ & $\begin{array}{c}0.00177 \\
(0.00429)\end{array}$ & $\begin{array}{l}-0.00436 \\
(0.00538)\end{array}$ \\
\hline Lived in a city & $\begin{array}{c}0.0205 \\
(0.0117)\end{array}$ & $\begin{array}{c}0.0106 \\
(0.00644)\end{array}$ & $\begin{array}{c}0.0415^{* * *} \\
(0.0117)\end{array}$ & $\begin{array}{l}0.0214^{* *} \\
(0.00982)\end{array}$ & $\begin{array}{c}0.0350^{* * *} \\
(0.00893)\end{array}$ & $\begin{array}{l}0.0264^{* *} \\
(0.00933)\end{array}$ & $\begin{array}{l}0.0231^{*} \\
(0.0113)\end{array}$ & $\begin{array}{c}0.0359 * * \\
(0.0124)\end{array}$ \\
\hline Lives in a town & $\begin{array}{c}0.0186^{*} \\
(0.00934)\end{array}$ & $\begin{array}{c}0.0236^{* * *} \\
(0.00764)\end{array}$ & $\begin{array}{c}0.0292^{* * *} \\
(0.00866)\end{array}$ & $\begin{array}{c}0.0273^{* * *} \\
(0.00581)\end{array}$ & $\begin{array}{c}0.0168 \\
(0.00976)\end{array}$ & $\begin{array}{c}0.0144 \\
(0.0105)\end{array}$ & $\begin{array}{c}0.0172^{* * *} \\
(0.00452)\end{array}$ & $\begin{array}{c}0.0120 \\
(0.00833)\end{array}$ \\
\hline Age & $\begin{array}{c}0.00260 * * * \\
(0.000289)\end{array}$ & $\begin{array}{c}0.00255^{* * *} \\
(0.000374)\end{array}$ & $\begin{array}{c}0.00220^{* * *} \\
(0.000238)\end{array}$ & $\begin{array}{c}0.00269^{* * *} \\
(0.000294)\end{array}$ & $\begin{array}{c}0.00247^{* * *} \\
(0.000212)\end{array}$ & $\begin{array}{c}0.00266^{* * *} \\
(0.000273)\end{array}$ & $\begin{array}{c}0.00258^{* * *} \\
(0.000250)\end{array}$ & $\begin{array}{c}0.00252^{* * *} \\
(0.000287)\end{array}$ \\
\hline Observations & 28,686 & 27,843 & 28,603 & 29,049 & 27,428 & 28,921 & 26,947 & 24,668 \\
\hline R-squared & 0.018 & 0.018 & 0.016 & 0.021 & 0.020 & 0.022 & 0.023 & 0.023 \\
\hline Number of countries & 15 & 15 & 15 & 15 & 15 & 15 & 15 & 14 \\
\hline
\end{tabular}

Note: Dependent variable: vote for a social democratic party. Estimation: Linear probability model with country fixed-effects. Baselines: female, lives in a rural area, other professional and socio-economic status. Data from the 8 waves of the European Social Survey. Countries included: Belgium, Finland, France, Germany, Hungary, Netherlands, Norway, Poland, Portugal, Slovenia, Spain, Sweden, Switzerland, and United Kingdom. Standard errors in parentheses. 